\title{
River basins as social-ecological systems: linking levels of societal and ecosystem water metabolism in a semiarid watershed
}

\author{
Violeta Cabello $^{1}$, Barbara A. Willaarts $^{2}$, Monica Aguilar $^{3}{ }^{\text {and Leandro del Moral Ituarte }}{ }^{1}$
}

\begin{abstract}
River basin modeling under complexity requires analytical frameworks capable of dealing with the multiple scales and dimensions of environmental problems as well as uncertainty in the evolution of social systems. Conceptual and methodological developments can now be framed using the wide socio-eco-hydrological approach. We add hierarchy theory into the mix to discuss the conceptualization of river basins as complex, holarchic social-ecological systems. We operationalize the social-ecological systems water metabolism framework in a semiarid watershed in Spain, and add the governance dimension that shapes human-environment reciprocity. To this purpose, we integrate an eco-hydrological model with the societal metabolism accounting scheme for land use, human activity, and water use. We explore four types of interactions: between societal organization and water uses/demands, between ecosystem organization and their water requirements/supplies, between societal metabolism and aquatic ecosystem health, and between water demand and availability. Our results reveal a metabolic pattern of a high mountain rural system striving to face exodus and agricultural land abandonment with a multifunctional economy. Centuries of social-ecological evolution shaping waterscapes through traditional water management practices have influenced the eco-hydrological functioning of the basin, enabling adaptation to aridity. We found a marked spatial gradient on water supply, use pattern, and impact on water bodies from the head to the mouth of the basin. Management challenges posed by the European water regulatory framework as a new driver of social-ecological change are highlighted.
\end{abstract}

Key Words: holarchy; river basin; socio-eco-hydrology; social-ecological systems; water availability; water metabolism

\section{INTRODUCTION}

Water resources degradation is a complex environmental problem that involves multiple dimensions and scales of analysis. As the awareness over the human alteration of the global water system gained acceptance within the scientific community, the connections of local processes to global drivers and of human and environmental systems became key research objects (Vörösmarty et al. 2013). Watersheds have been the traditional observation system for hydrological studies focused on the reproducibility of water resources within the water cycle. Water basins are both a biophysical unit for hydrological modeling and a governance tool for water decision making in many countries (Cohen and Davison 2011, Del Moral and Do Ó 2014). As such, institutional performance and governance structures are drivers of change as much as biophysical and socioeconomic processes. Recent efforts of integrated river basin modeling strive to predict the effects of decision making on water allocation and land uses over the hydrological system under a range of scenarios (Jakeman and Letcher 2003, Henriques et al. 2008, Liu et al. 2008). Although these models are powerful in hydrological response forecasting, uncertainty in societal choice predictions is still a major challenge (Letcher et al. 2007). This is partially because of the local specificity of the complex organization of social systems as driver for environmental change, making extrapolation between contexts difficult. Nevertheless, water accounting methods, like virtual water (Allan 1998), water footprint (Hoekstra and Chapagain 2006), or social metabolism (Fischer-Kowalski 1998, Swyngedouw 2006) have engaged in trying to understand the socioeconomic and political drivers of water-use patterns, attempting to bridge scale mismatches with biophysical variables. Insights on the interactions between social, ecological, and hydrological processes have been proposed within analytical frameworks of social-ecological systems (SES; Madrid et al. 2013).

Complexity theory deals with the epistemological implications of: (1) multiple scales and dimensions of analysis and (2) high stakes and uncertainty in decision making in coupled humanenvironmental systems (Liu et al. 2007). The representation and analysis of river basins as complex SES is still incipient, although some important works have been developed recently. Rathwell and Peterson 2012 addressed cross-scale interactions between water management and the provision of ecosystem services. PahlWostl et al. (2010) proposed the management and transition framework for the analysis of water governance regimes, which they have later applied in at least 29 river basins all over the world (Pahl-Wostl et al. 2012). Mix et al. 2015 combined qualitative and quantitative methods to approach a diachronic analysis of multidimensional drivers of water-use change in an arid river basin. All these studies have two things in common: they depart from a networks approach to SES (Janssen et al. 2006), and they emphasize the role of policies and institutions shaping relations between social and ecological systems. However, none of them combine eco-hydrological modeling with socioeconomic quantitative analysis as integrated watershed modeling does, and none deal with the multiscale organization of SES.

Hierarchy theory is another branch of complexity approaching the analysis of SES (Pattee 1973, Allen and Starr 1988, Giampietro 2003). Networks theory and hierarchy theory are not exclusive but rather complementary analytical lenses, each having strengths and purposes (Allen and Giampietro 2014). Although network approaches to SES gain analytical dynamism by focusing

${ }^{1}$ Department of Human Geography, University of Seville, ${ }^{2}$ Research Centre for the Management of Agricultural and Environmental Risks -

CEIGRAM, Technical University of Madrid., ${ }^{3}$ Department of Physical Geography, University of Seville 
on change with conceptual devices such as drivers, thresholds, and resilience, hierarchy theory is more robust on scaling issues and looking for principles of categorization of living systems organization by using concepts such as descriptive domain, surfaces, or holons. Madrid and Giampietro (2015) build on hierarchy theory to propose an analytical framework for complex SES based on the concept of water metabolism (SESWM). They strive to address the coexistence of multiple intertwined multilevel organizations of the different subsystems of a SES. According to the classification criteria for analytical frameworks of SES posed by Binder et al. (2013), the SESWM is an anthropocentric analysis-oriented framework that deals with the reciprocity among social and ecological systems by focusing on the feedbacks between their organization and their water exchange. Nonetheless, it does so through quantitative indicators without addressing the institutional layers of that reciprocity. We attempt to operationalize the SESWM framework to analyze the sustainability of water management in a semiarid Spanish watershed, the Upper Andarax. To this purpose, we integrate the eco-hydrological model BalanceMED (Willaarts et al. 2012) in the multiscale integrated analysis of societal and ecosystems metabolism (MuSIASEM) accounting scheme (Giampietro et al. 2009, 2011, 2014), and we add the governance dimension. We aim to look at the following questions: how does the socio-ecohydrological functioning of the Upper Andarax Watershed work? What are the main drivers of socioeconomic change and their impacts over aquatic ecosystems? What are the water management challenges in the context of the current European water regulatory framework? What are the trade-offs associated with water management decisions?

\section{STUDY AREA}

The Upper Andarax Watershed is located in the southeastern part of the Iberian Peninsula in Almeria Province. According to the nomenclature of the European Union Water Framework Directive (EC 2000), it is part of the Andarax River basin, water exploitation system IV of the Andalusian Mediterranean River Basin District (Fig. 1). The Upper Andarax is a genuine catchment because of its uneven topography and its striking hydraulic heritage. The narrow valley runs between two great elevations, the Sierra Nevada foothills, to the north, and Sierra de Gador to the south. Land occupation in the Upper Andarax is extremely constrained by topography, with agriculture occupying $14 \%$ of the territory. Vegetation series correspond to Quercus spp. in the meso-mediterranean zone (until $1280 \mathrm{~m}$ ) and Juniperus spp. in the supra-mediterranean zone (up to $2000 \mathrm{~m}$ ), but representatives of these species are now very limited. Pinus spp. plantations are the most extended forest form usually mixed with shrubs. The major vegetation cover includes different types of xerophytic shrubs, well-adapted to the prevailing arid conditions. Predominant species are Stipa tenacissima (esparto), Ulex parviflorus, and Festuca scariosa. A system of traditional irrigation infrastructure (infiltration channels called "acequias," flood collection "turbias," and subsurface water collection "galerias") and their local management communities have long ensured water availability in this dry environment (Pulido-Bosch and Sbih 1995). The social-ecological interest of the basin has driven a large amount of rich historical studies in the area (the Martínez and Usero 2010 book is a good compilation), yet there is less scientific literature on current socio-eco-hydrological functioning of the basin (Sánchez-Martos et al. 2013).
Fig. 1. Upper Andarax and its location within the Andarax River basin.

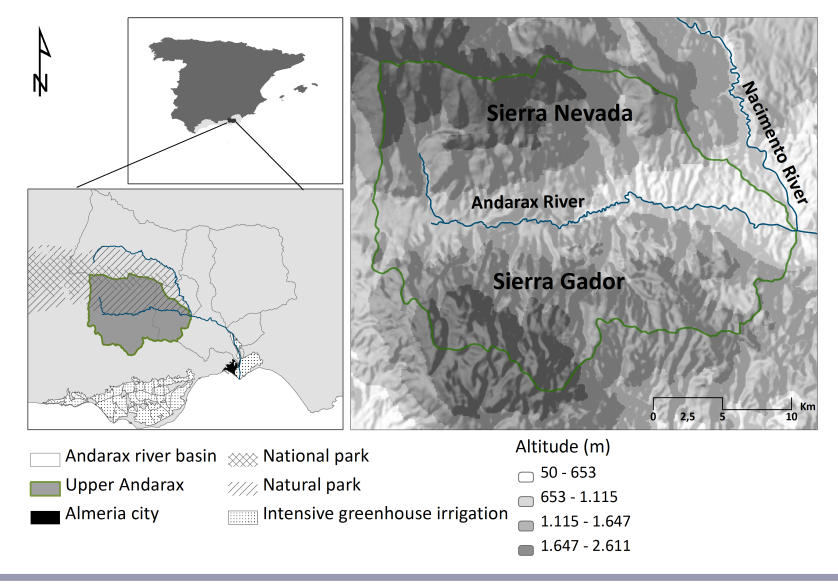

Human-environmental relations in the Upper Andarax are described from the Neolithic. We focus on the period when the international economic and political arena became key drivers for regional change. Contrary to other regions in Spain, Almeria had, from the onset of 19th century, an export-based economy thanks to its important harbor (Sánchez-Picón et al. 2011; Table 1). This first globalization brought a flourishing lead mining activity lasting over a century until its international depreciation. The depression was succeeded by a second mining boom, the iron time, as well as the cultivation of grapes, oranges, and esparto grass, which were in high demand in England through much of the 20th century. These activities drove major land-use changes, including a massive process of deforestation, which forced the development of an impressive system of agricultural terraces on the riverbanks to reduce the risk to floods (Latorre et al. 2001). Miners excavated cisterns, which collected subsurface water flow for agriculture, leading to the creation of important water user communities to manage the new resources. Much of the mountainous areas were also terraced and reforested with Pinus spp. during the reforestation campaigns of the Franco's dictatorship (Martínez et al. 2008). The second globalization begun at the end of 19th century and elicited the decline of this economy and the first emigration boom between 1980-2000 (Sánchez-Picón et al. 2011). Part of this boom followed an internal drift from upper mountain areas to the coast where the grape cultivation infrastructure was repurposed to introduce intensive vegetable production in plastic greenhouses for distribution in the European market (Mateo 2013).

The northern Sierra Nevada is one of the most important hotspots for plant diversity and endemism in the Western Mediterranean region and includes an impressive geomorphological system with more than 15 peaks over 3000 meters at $50 \mathrm{~km}$ from the sea. It was declared a biosphere reserve in 1986 by UNESCO and a natural park, aimed at integrating sustainable human activities within conservation goals, by the Andalusian government in 1989. The most ecologically valued area, i.e., the higher peaks covered by snow in winter, was declared a national park in 1999, phasing out traditional human activities like agriculture, hunting, and gathering within its boundaries. 
Table 1. Drivers of social-ecological change.

\begin{tabular}{|c|c|c|c|}
\hline International driver & Regional driver & Period & Social-ecological changes \\
\hline First globalization & Mining & $\begin{array}{l}\text { End of } 18 \text { th - } \\
\text { end of } 19 \text { th }\end{array}$ & Deforestation, floods, cisterns excavation \\
\hline \multirow[t]{2}{*}{ Economic crisis } & Grape production & $\begin{array}{l}\text { End of } 19 \text { th - } \\
\text { end of } 20 \text { th }\end{array}$ & Terrace system \\
\hline & Reforestations & 1939-1975 & Pine plantations extension \\
\hline Second globalization & $\begin{array}{l}\text { Emergence of greenhouse production in } \\
\text { coastal area }\end{array}$ & $1980-2000$ & Rural exodus, agricultural land abandonment \\
\hline $\begin{array}{l}\text { United Nations Program Man and the } \\
\text { Biosphere }\end{array}$ & Sierra Nevada protection & 1986-1999 & Land uses regulation \\
\hline Water Framework Directive & Environmental objectives achievement & $2010-2027$ & Good ecological status of water bodies \\
\hline Common Agricultural Policy & $\begin{array}{l}\text { Competitiveness within international } \\
\text { markets }\end{array}$ & $2008-2014$ & Agricultural intensification \\
\hline
\end{tabular}

The basin currently consists of an aged population of 8873 inhabitants distributed in 14 municipalities (INE 2011). However, the pictorial agricultural landscape is an identity element being gradually abandoned as agricultural productivity decreases. The main occupations in the upper municipalities closer to the national park are related to ecotourism, turning to agriculture in the central part until the last municipalities at the mouth of the basin, which are mainly working in the services sector.

Current challenges posed by European water and agricultural policies derive from their planning objectives, which are usually conflicted (Cabello Villarejo and Madrid López 20142014). The European water governance strategy was set with the Water Framework Directive in the year 2000. As exemplary implementation of the integrated water resources management paradigm, each river basin in Europe had to establish a new adaptive management regime in planning cycles of six years. The overall objective is the recovery of "good ecological status" of all water bodies in Europe by 2015. The first river basin management plan for the Mediterranean Andalusian River Basin District was released in 2010. The plan assessed, for the first time, the ecological status of surface and groundwater bodies in the region and established environmental recovery objectives for the time horizons of 2015 and 2027.

\section{METHODS}

River basins as complex holarchic social-ecological systems

River basins have been represented using different analytical lenses: hydrological, ecological, institutional, or socioeconomic (Fig. 2a). Each analytical dimension is a criterion for observation and can itself be approached as a hierarchy with multiple nested levels. Hierarchies have been described for ecosystems (Allen and Hoeckstra 1992, Jørgensen and Nielsen 2013), hydrological systems (MacLachlan and Moulton 2006, Li and Ren 2010), institutions (Gupta and Pahl-Wostl 2013), agro-ecosystems (Giampietro 2003, Ewert et al. 2011), and social systems (Scholz and Binder 2003, Giampietro et al. 2014). All of these criteria are relevant when conceptualizing the river basin as a socialecological system. The dual fuzzy identity of levels in a hierarchy, which are at the same time parts and wholes, structural compartments (a water mass) and functional types (a typology of water bodies), is captured by the concept of holon (Koestler 1972, Serrano-Tovar and Giampietro 2014). Feedback loops occur within holons and across levels and dimensions. The problem is how to operationalize the existence of these coexisting holons in a common frame of analysis and deal with the transfer of information between descriptive domains. In research practice, this has been tackled through the institutional analysis of environmental governance regimes in some of the most popular frameworks for SES analysis (Scholz and Binder 2003, Ostrom 2009, Pahl-Wostl et al. 2010).

Fig. 2. (a) Descriptive domains for a river basin. Adapted from Ewert et al. (2011); (b) Multiaxes holarchy for a river basin as a social-ecological system (SES). Adapted from Madrid and Giampietro (2015).

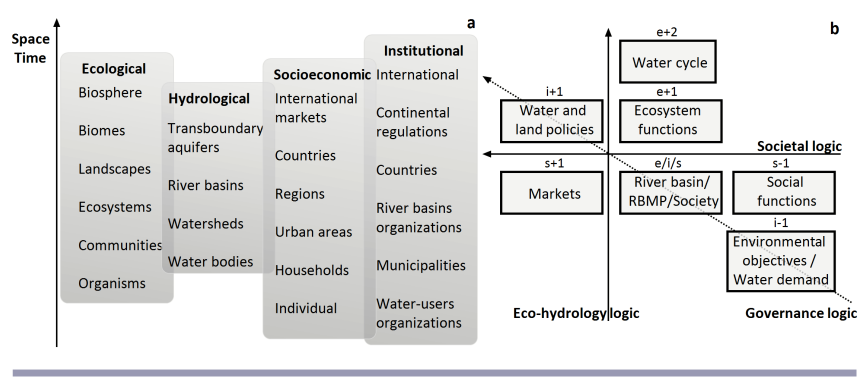

Madrid and Giampietro (2015) propose the combination of the two classical descriptive domains in hydrological studies: the "watershed" (eco-hydrology logic, "e") and the "problemshed" (societal logic, "s") in a holarchic basis (Fig. 2b). Any holon is composed of a physical part that exchanges biophysical flows to reproduce itself and a coded part that handles its information (Allen and Giampietro 2014). We add a transversal axis representing the "infoshed" (governance logic, "i") produced at different levels that shape societal metabolic patterns and interaction with their contextual environment. Our focal level (e/ $\mathrm{i} / \mathrm{s}$ ) is the physical river basin and its society, linked through the river basin management plan (RBMP), which establishes water allocations. Upper and lower levels in the axes establish the external and internal constraints to the self-organization of the socio-ecosystem.

We structure the multiaxes into the general analytical framework (Fig. 3) arranging analytical categories in four quadrants: ecosystem/societal metabolism and water exchange/organization. 
Hydrological processes in a watershed sustain a wide range of ecosystem services. A great part of the rainfall within a basin is stored in the soils and evapotranspired by plants, providing services like microclimate regulation, rain-fed agriculture, or forest products. Another share of the annual rainfall flows into aquatic ecosystems and is often regulated to ensure human water supply through the development of infrastructures (technical capital). Water, land, and other environmental policies affect how much water is stored in soils and water bodies by normatively setting environmental objectives, aquatic ecosystem requirements, land-use changes, and new infrastructure developments. These policies are usually produced at higher governance levels than the basin itself, framing the strategies for river-basin management, which then have to encounter local realities. We represent four interfaces in which we can address different types of interactions between (1) the organization of social systems and water use/ demand (A), (2) water demand and water availability (B), (3) the organization of ecosystems and water supply (C), and (4) the organization of societal metabolism and ecosystem health (D).

Fig. 3. Social-ecological system based on the concept of water metabolism (SESWM) analytical framework adapted from Madrid and Giampietro (2015) to the Upper Andarax basin.

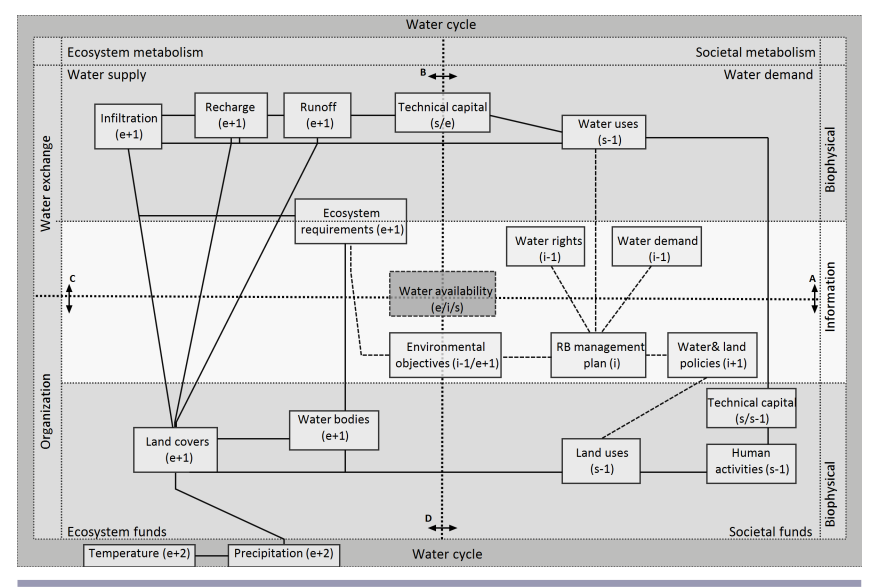

\section{Water availability}

Water availability is a concept approached from multiple definitions and perspectives (Table 2). The most common one refers to the long-term average freshwater volume yearly supplied by the hydrological cycle, including runoff and aquifer recharge (see for instance Menzel and Matovelle 2010, Parish et al. 2012, Post et al. 2012). In this sense, it equates to the Falkenmark and Rockström (2004) concept of blue water. Other approaches encompass the environmental flows (e-flows) as a prior allocation to what is available for humans (Poff et al. 2010, Hoekstra et al. 2012) or focus on the reproducibility of specific end uses (Henriques et al. 2008, Molden et al. 2011, Padowski and Jawitz 2012).

Availability, in a social-ecological sense, is a dynamic boundary concept between societal water uses, expectations on additional water requirements (demand), technical capital to regulate water bodies, and desired ecosystem integrity. Defining availability is the process of determining what is considered a resource for a specific, usually human end use, and what is not. For instance, on fined aquifers water "becomes available" when technological advances and energy prices allow deeper pumping, as long as there are no adverse effects that the social system using the groundwater is not willing to accept (del Moral 2005:16, Zhou 2009). As a normative category, water availability depends on which are the accepted trade-offs between water extraction and environmental, economic, and social consequences of this extraction. Because narratives on availability might differ depending on whom you ask, especially when water allocation implies uncertainties and high stakes, a normative definition of availability is usually set as a compromise to avoid conflicts, or as an imposition of a party, in the frequent case of existence of unbalanced power relations. Despite formal commitments or authoritarian impositions, the implementation of the resulting standards are often subjected to infringements, a not incidental but structural atmosphere of deviance or noncompliance with legal norms. This is the case of the region in which the Andarax is located (Sampedro and Del Moral 2014). Nonetheless, what is allocated as available at one scale for an end use will entail trade-offs, and thus, create winners and losers. Therefore, further negotiation with those affected is usually required. For instance e-flows established in European river basins are calculated first and negotiated afterwards (see for instance section 4.3.6 of the Spanish water legislation http://www. magrama.gob.es/es/agua/legislacion/iph_tcm7-207591.pdf).

Table 2. Water availability definitions for different systems.

\begin{tabular}{|c|c|c|}
\hline System & Water availability & Trade-offs \\
\hline $\begin{array}{l}\text { Whole social- } \\
\text { ecological } \\
\text { system }\end{array}$ & $\begin{array}{l}\text { Total water inflow to the river } \\
\text { basin including precipitation } \\
\text { (minus evapotranspiration), } \\
\text { inflow from other aquifers, and } \\
\text { from external transfers }\end{array}$ & $\begin{array}{l}\text { With other river } \\
\text { basins }\end{array}$ \\
\hline $\begin{array}{l}\text { Land } \\
\text { subsystem }\end{array}$ & $\begin{array}{l}\text { Soil water that can be used for } \\
\text { plant transpiration }\end{array}$ & $\begin{array}{l}\text { Between } \\
\text { productive and } \\
\text { nonproductive } \\
\text { uses }\end{array}$ \\
\hline $\begin{array}{l}\text { Aquatic } \\
\text { subsystem }\end{array}$ & $\begin{array}{l}\text { Ecosystem requirements of } \\
\text { surface and groundwater } \\
\text { (normatively established) }\end{array}$ & $\begin{array}{l}\text { With societal } \\
\text { appropriation }\end{array}$ \\
\hline $\begin{array}{l}\text { Human } \\
\text { subsystem }\end{array}$ & $\begin{array}{l}\text { Total water available for human } \\
\text { direct appropriation from } \\
\text { different sources }\end{array}$ & $\begin{array}{l}\text { Between human } \\
\text { demand and } \\
\text { impact on } \\
\text { ecosystems }\end{array}$ \\
\hline End users & $\begin{array}{l}\text { Water that can be used by each } \\
\text { end user according to institutional } \\
\text { regulation }\end{array}$ & $\begin{array}{l}\text { Between end } \\
\text { users }\end{array}$ \\
\hline
\end{tabular}

When moving from semantic to formal categories of water metabolism analysis, we need to make explicit the definition of water availability being considered. This definition is at the core of any water use sustainability assessment and introduces a value judgment into the scientific analysis, a preanalytical decision made by the analyst. Molle and Mollinga (2003) defined water scarcity in terms of scarcity of what and for what. When using normative concepts such as sustainability, scarcity, or availability, these questions become relevant: availability of which type of resource, for what type of end use, at what costs, and for whom. In the interface of society and ecosystem, the definition of available water (Box 1) deals with the trade-offs between allocation of water for productive uses or ecosystem conservation. 
Box 1: Water availability at the ecosystems/society interface.

Water availability for society $=\sum$ (surface + groundwater + produced + transferred + soil) available water

Surface available water $=$ Compromised diversion from the river and reservoirs within established environmental flow regime for aquatic ecosystems

Groundwater available water $=$ Compromised pumping rate within an established sustainable yield

Reclaimed available water $=$ Wastewater reuse + desalination capacity

Transferred available water $=$ Transfers from other basins

Soil available water $=$ Soil moisture appropriated for human use for plant growth and food production

\section{The water grammar in multiscale integrated analysis of societal and ecosystem metabolism (MuSIASEM)}

Our methodological purpose is the operationalization of SESWM to link the analysis of societal metabolism to variables of ecosystem metabolism that are relevant for river basin management. Our lenses are on the social scale of observation: we do not study the functioning of ecosystems themselves but the interactions between ecosystems and society as a consequence of societal organization. Therefore, as an ecosystem water metabolism analysis, we focus on the eco-hydrological processes that control water resource renewability (supply side), the impacts caused to ecosystem health ( ink side), and the boundary concepts of water availability and ecosystem water requirements. To this purpose, water metabolism is quantified through the water grammar, tying the semantic representation of the system metabolism (Fig. 3) to the holarchic organization considered (Fig. $2 b)$.

A grammar is a formal system of rules for accounting metabolic flows, given a set of expected relationships between semantic categories of what we want to indicate (for instance sustainability) and formal categories (indicators, data, and rules for calculation). The MuSIASEM uses different interrelated grammars for the water, energy, land, and food nexus (see Giampietro et al. 2014), based on the flow-fund model of Georgescu-Roegen (1971). Fund variables are those remaining the same over the time duration of the representation (or those that we want to conserve) whereas flows are those that are consumed or produced to maintain and reproduce funds. Common societal funds used in MuSIASEM are human activity (measured in hours), technical capital, and land. Land is, at the same time, an ecological and societal fund. The specificity of water as a resource is important in that it changes its semantic definition from a fund in ecosystems (longterm patterns of water cycle change) to a flow in most societal uses (managed through year planning). Note that, although most approaches consider water bodies as stocks (see for instance Falkenmark and Rockström 2004), the difference between stocks and funds is essential in the metabolism approach (Giampietro and Lomas 2014). Stocks are nonrenewable resources at the time scale of the representation, like reservoirs or aquifer overdraft, which consumptive use diminishes availability for ecosystems or for future needs. Funds are resources consumed at a slower pace than their renewability rate during the representation, like aquifer sustainable yield or soil moisture. Ecosystems live on water fund limits. Water flows for human use can come from a stock or a fund because we can create artificial stocks to increase available water flows or overdraft funds from remaining stocks (fossil waters).

The water grammar provides a set of useful semantic categories for multilevel accounting of ecosystems (e \pm i) and societal (s \pm i) water metabolism (Madrid and Giampietro 2014; Table 3). Flows and funds are classified in typologies explicitly tailored to each case study according to criteria defined at each level of observation. Water flows are typologies associated with provisioning ecosystem services that change water characteristics in its use. Water funds sustain ecosystem functions that supply all types of services. There are also human uses of water funds, like navigation or electrical generation, which are not relevant to this case study. Water funds are required all at once whereas flows are required at a specific pace. In addition, they are all required to have a specific set of useful attributes, i.e., quantity, quality, timing, and location (Brauman et al. 2007).

The grammar is quantified through extensive variables (total flows and funds), and relational indicators (flow/flow, flow/fund) are summarized in Table 4. As shown in Figure 3, we consider four types of interactions between ecosystems and society. Relation A describes the intensity of water use required to maintain a human activity or land use. Relation B describes the degree of exploitation of water funds (supply side) for direct human uses. Relations type $\mathrm{C}$ are two-sided: on one hand, the generation of water funds (runoff, recharge, soil infiltration) per type of land cover; on the other, the ecosystem water requirements mediated by normative societal decisions on availability and land uses. The feedback D, environmental loading, refers to the impact of the societal metabolism over aquatic ecosystem health (sink side).

\section{Modeling}

To build up this grammar into formal categories several models/ tools have been integrated:

- Climate: a series of monthly median precipitation and mean temperature measurements for the period 1970/1971-2000/2001 from 24 meteorological stations have been interpolated through inverse distance weighting (IDW) in ArcGIS 10.2 and used for potential evapotranspiration calculation with a Thornthwaite based Microsoft Excel macro.

- Eco-hydrology: the BalanceMED model (Willaarts et al. 2012) is a semideterministic model able to quantify the mean hydrological functioning (i.e., partition of annual precipitation into runoff, aquifer recharge, and soil moisture) of Mediterranean basins using long time series of mean monthly rainfall and potential evapotranspiration. Because BalanceMED is a spatially explicit model, the Upper Andarax was divided into so-called hydrological units (HU), which are unique combinations of Land Use Land Cover (LULC) and soil types. Such divisions allow the identification of potential differences in the ecohydrological functioning across the basin. The model uses the APLIS equation (Andreo et al. 2004) to assess the soil percolation capacity (i.e., potential aquifer recharge). 
Table 3. Water grammar for the Upper Andarax basin. Adapted from Madrid and Giampietro (2014).

\begin{tabular}{|c|c|c|c|c|c|c|}
\hline \multirow{2}{*}{$\begin{array}{l}\text { System } \\
\text { definition }\end{array}$} & \multicolumn{3}{|c|}{ Water Exchange } & \multicolumn{3}{|c|}{ Organization } \\
\hline & Role & $\begin{array}{l}\text { Semantic } \\
\text { categories }\end{array}$ & Types & Role & $\begin{array}{l}\text { Semantic } \\
\text { categories }\end{array}$ & Types \\
\hline $\begin{array}{l}\text { Water cycle } \\
\mathrm{e}+2\end{array}$ & Fund & Climate & Precipitation & Fund & Climate & Potential Evapotranspiration \\
\hline $\begin{array}{l}\text { Ecosystem } \\
\text { functions } \\
e+1\end{array}$ & & $\begin{array}{l}\text { Water funds } \\
\text { turnover }\end{array}$ & $\begin{array}{l}\text { Runoff } \\
\text { Recharge } \\
\text { Infiltration }\end{array}$ & & Land covers & $\begin{array}{c}\text { Quercus and riparian forests } \\
\text { Plantations } \\
\text { Shrubs } \\
\text { Pastures } \\
\text { Irrigated agric. } \\
\text { Rain-fed agric. } \\
\text { Abandoned agric. }\end{array}$ \\
\hline $\begin{array}{l}\text { Water funds } \\
\text { Focal level e }\end{array}$ & & $\begin{array}{l}\text { Available water for } \\
\text { societal } \\
\text { appropriation }\end{array}$ & $\begin{array}{l}\text { Surface } \\
\text { Groundwater } \\
\text { Soil moisture }\end{array}$ & & Water bodies & $\begin{array}{l}\text { Rivers } \\
\text { Aquifers }\end{array}$ \\
\hline $\begin{array}{l}\text { Society } \\
\text { Focal level s }\end{array}$ & Flow & Gross water use & $\begin{array}{l}\text { Withdrawn } \\
\text { Soil }\end{array}$ & Fund & Human activity & $\begin{array}{c}\text { Physiological overhead } \\
\text { Social, Leisure, and Education } \\
\text { Unpaid work } \\
\text { Paid work }\end{array}$ \\
\hline $\begin{array}{l}\text { Societal } \\
\text { functions } \\
\text { s-1 }\end{array}$ & & Net water use & $\begin{array}{l}\text { Urban supply } \\
\text { Food production } \\
\text { Forestry } \\
\text { Esparto gathering } \\
\quad \text { Cattle }\end{array}$ & & $\begin{array}{l}\text { Managed land } \\
\text { uses }\end{array}$ & $\begin{array}{c}\text { Plantations } \\
\text { Shrubs } \\
\text { Pastures } \\
\text { Irrigated agric. } \\
\text { Rain-fed agric. }\end{array}$ \\
\hline i-1 & & Demand & Withdrawals & & Technical capital & $\begin{array}{c}\text { Transport infrastructures Irrigation } \\
\text { technology }\end{array}$ \\
\hline & & & & Flow & Money & $\begin{array}{l}\text { Agricultural costs } \\
\text { Gross added value water costs } \\
\text { Municipal gross rent }\end{array}$ \\
\hline
\end{tabular}

Table 4. Relational indicators.

\begin{tabular}{|c|c|c|}
\hline Relation & Indicator & Description \\
\hline A & Water metabolic rate & $\begin{array}{l}\text { Gross water use per hour of human } \\
\text { activity }\end{array}$ \\
\hline B & $\begin{array}{l}\text { Water extraction } \\
\text { index }\end{array}$ & $\begin{array}{l}\text { Surface water: ratio of water } \\
\text { withdrawals out of total runoff, e- } \\
\text { flows discounted } \\
\text { Groundwater: ratio of water } \\
\text { abstraction out of total recharge, } \\
\text { discharges to springs discounted }\end{array}$ \\
\hline \multirow[t]{2}{*}{$\mathrm{C}$} & $\begin{array}{l}\text { Environmental } \\
\text { impacts }\end{array}$ & Surface and groundwater quality \\
\hline & & $\begin{array}{l}\text { Water table level changes } \\
\text { Erosion rates }\end{array}$ \\
\hline $\mathrm{D}$ & $\begin{array}{l}\text { Ecosystems water } \\
\text { requirements }\end{array}$ & $\begin{array}{l}\text { Soil: transpiration } \\
\text { River: e-flows } \\
\text { Groundwater: discharge to springs }\end{array}$ \\
\hline
\end{tabular}

- Societal metabolism accounting: this includes water and monetary flows and land, human activity, and technical capital funds. We use the pie chart representation for ruralsystems analysis adapted from the Serrano-Tovar and Giampietro (2014) template. It includes their interactions with three types of contexts, i.e., urban system, external markets, and water funds. Associated land-cover uses and green water flows were estimated with a fuzzy approach of shares-use coefficients per type of cover (see Appendix 1).
Fig. 4. Process overview.

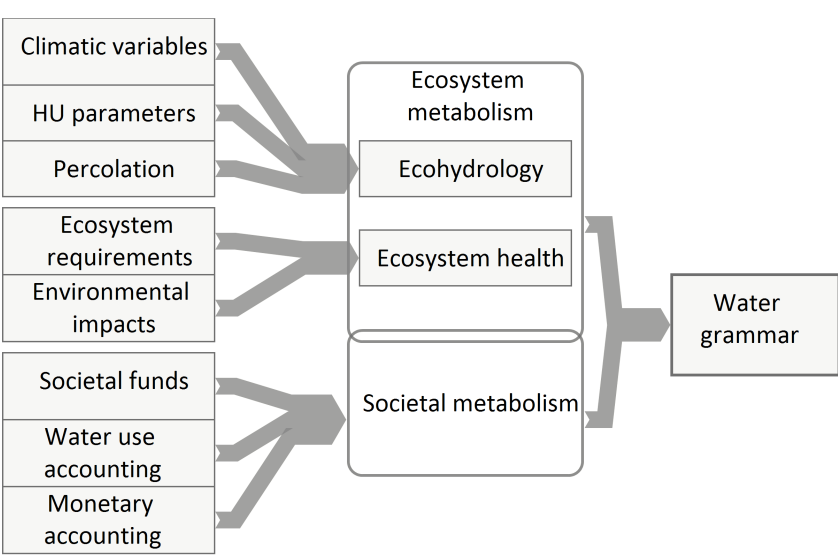

- Environmental impacts: annual rates for erosion and water table level changes have been averaged for available series between 1992 and 2006. Water-quality measurements in existing control points in the watershed were averaged for available series between 2002 and 2013.

The process consisted of spatial processing of the physical variables in ArcGIS 10.2 to feed the eco-hydrological model on one side, and on secondary data processing to feed the societal metabolism accounting on the other (Fig. 4). Both were 
conducted in $\mathrm{R}$, and results were gathered in ArcGIS geodatabases. Results, analysis, and discussion were completed through two months of fieldwork observations and nine semistructured interviews of key informants in the basin (MarchApril 2014). For a detailed methodological description on data sources, model calibration, variables calculation, and links to databases and codes please refer to the methodology in Appendix 1. Note that the levels specified in the grammar follow an organizational scale of observation, i.e., holons in a socialecological system. Formal categories of the grammar and the spatial and temporal scales used for modeling are given in Table 1 and Figure 1 of the Appendix.

\section{How do we calculate water availability?}

As Del Moral (2005) and Zhou (2009) illustrated, water availability is almost impossible to calculate on a general basis because of its strong dependency on normative frameworks, technical capital, and accepted trade-offs of water withdrawal. The Spanish water management legislation only defines water availability for groundwater as "the average year-to-year value of total recharge of the water body minus the average year-to-year flow required to achieve environmental objectives, to prevent any further significant deterioration of the ecological status and significant damage of dependent terrestrial ecosystems" (MARM 2008). This complex definition is not complemented by a harmonized framework for its assessment, especially with regard to the connection of ground to surface water bodies, leaving the definition of "significant" damage open to interpretation. As a result, aquifers are usually treated as black boxes in the RBMPs, and the lack of spatially explicit aquifer modeling hinders their governance robustness (De Stefano et al. 2014). We calculate the year availability for societal appropriation based on available data as:

$$
\begin{aligned}
& W A_{\text {Surface }}=D S F-E F \\
& W A_{\text {Ground }}=R E+I R F+I I R+I F-O F-E F
\end{aligned}
$$

Where $D S F$ are water diversions from the river, $E F$ are the e-flows, $R E$ is the annual recharge from rain, $I R F$ the infiltration from runoff, $I I R$ the infiltration from irrigation returns, $I F$ the lateral inflow, and $O F$ the lateral outflows to other aquifers. We assumed the regime of surface e-flows estimated in the RBMP as well as the average annual estimated discharge to the 58 natural springs as a proxy for groundwater ecosystem dependency.

\section{Modeling limitations}

The most important drawback of our study is the unavailability of a temporal series of water-use data hampering a diachronic analysis. In addition, the wide and diverse secondary data requirements for the social metabolism analysis forces the integration of data measured in different periods. For this reason, we can only get a snapshot of the average water metabolism in the region between 2000 and 2008. This is the same timeframe as the baseline measurements produced for the RBMP released in 2010. Regarding the eco-hydrological model, the surfacegroundwater interactions and the influence of the snow on the hydrological regime are not considered. In addition, one of the main limitations is the difficulty to model the pronounced human alteration of the basin hydrology. We only consider human terracing with regard to its effect on slope reduction but their explicit relation to erosion rates is not covered within our model. We decided to calibrate on a monthly average resolution because it is sufficient for our descriptive purposes given the constraints on social data.

\section{RESULTS}

\section{Water funds $(\mathrm{e}+2 / \mathrm{e}+1)$}

The Upper Andarax climate is representative of Mediterranean areas: high evapotranspiration and marked seasonal and interannual irregularity of precipitation. Nonetheless, the high elevations of both sides of the basin and its orientation shape a harsh gradient in the spatial distribution of precipitation and potential evapotranspiration (Figs. 5a, b). The Northwest, mountainous Sierra Nevada presents a subhumid $630 \mathrm{~mm}$ of annual precipitation and temperature of $11{ }^{\circ} \mathrm{C}$. The lower, southeastern area is classified as semiarid with a range 200-300 $\mathrm{mm}$ of annual precipitation, mean temperatures of $16{ }^{\circ} \mathrm{C}$, and potential evapotranspiration of up to $890 \mathrm{~mm}$. The presence of arid zones, characterized by the alternation of extreme events (drought and torrential rainfall), is usually a more determining factor than the small fluctuations in the mean values of the climatological variables. This irregularity is revealed by annual Pearson's coefficients of variation around $42 \%$, increasing to over $200 \%$ for the driest months.

Water bodies are classified in typologies in the RBMP. There are two surface water bodies: the Alto Andarax, which runs from the spring until the first urban area, and the Medio Andarax, which continues then flowing down until the outlet. The two main groundwater bodies extend far beyond the watershed to coastal areas in which major exploitation takes place. Gador Sierra is a huge karst aquifer composed of permeable and fractured limestone and dolomites. As observed in Figure 5c, the recharge model shows a recharge capacity of over $80 \%$ for this area whereas siliceous Sierra Nevada has low permeability, and the detritus aquifer of Low Andarax medium (70-80\%). Total mean annual precipitation for the modeled period was $138.2 \mathrm{Hm}^{3}$; of which 76.6 turns into soil moisture, 36.4 percolates for aquifer recharge, and 15.7 flows as runoff. Figures $5 \mathrm{~d}-\mathrm{f}$ show the spatial distribution of these water funds. The influence of the precipitation pattern is clear in that $80 \%$ of runoff generation is concentrated in the northeast corner whereas most of the recharge is distributed all along the eastern strip. Middle and lower parts of the basin show lower runoff and recharge generation but still hold an important fraction of the soil moisture.

The average eco-hydrological indicators (Relations C) per landcover type are presented in Figure 6. Transpiration, as the share of soil water invested in biomass productivity, is shown along with the annual rate of water evaporation, i.e., nonproductive fraction of soil water. Although representative of a small fraction of the territory, Quercus spp. forests and its combination with other types of vegetation (shrubs or pastures) and riparian forests transpire the largest fraction of soil moisture, followed by Pinus spp. plantations. As expected, more densely vegetated areas are more efficient in terms of water used to produce a unit of biomass because they have less water losses from soil water evaporation. The ratio of transpiration out of total evapotranspiration decreases in lower covers, such as shrubs and pastures. The effect 
Fig. 5. Spatial distribution of (a) median annual precipitation; (b) potential evapotranspiration; (c) recharge capacity; (d) soil infiltration; (e) runoff; (f) recharge.
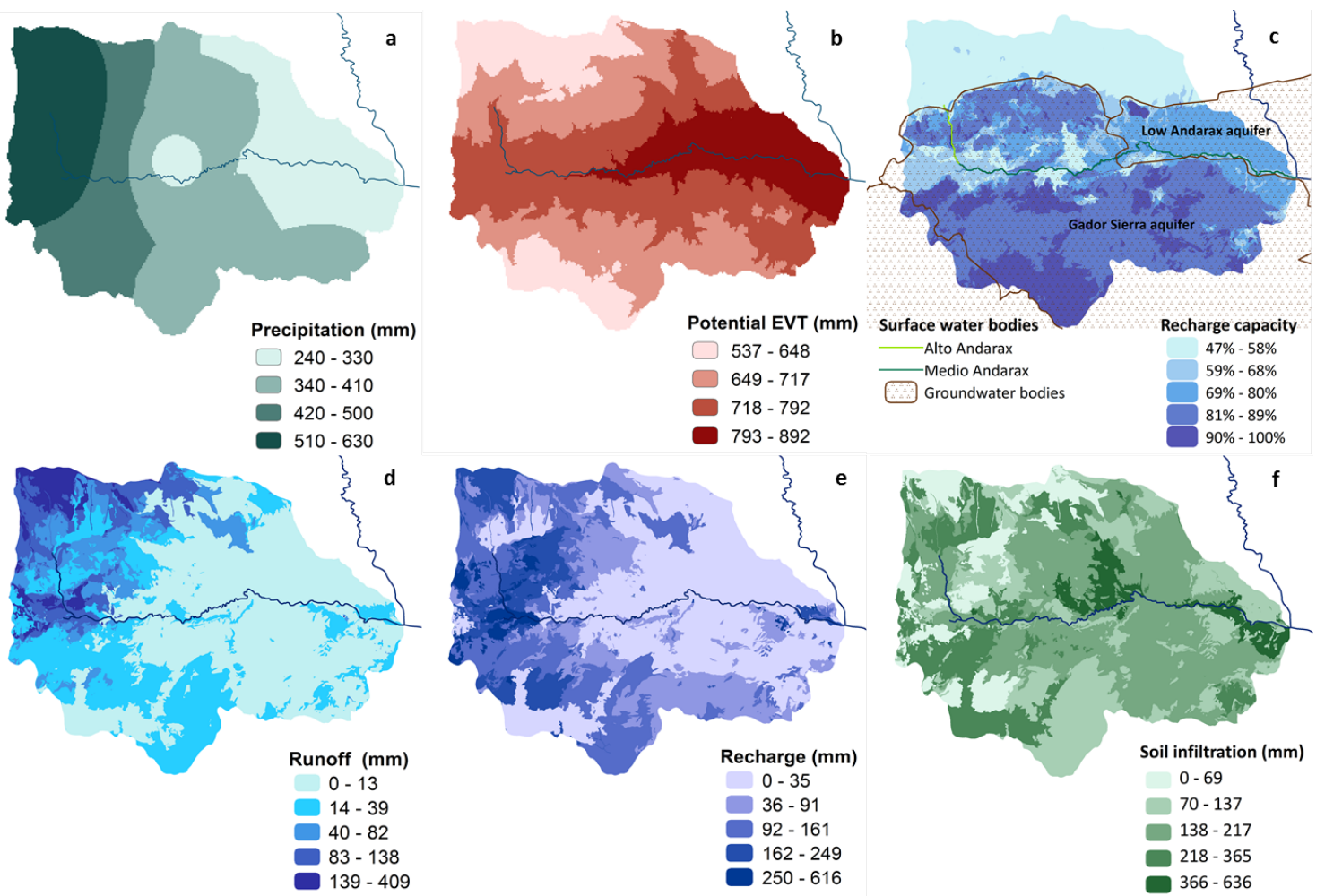

Potential EVT $(\mathrm{mm})$ Surface water bodies

$537-648$

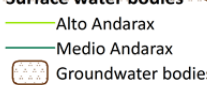

Recharge capacity

$649-717$

$718-792$

$793-892$

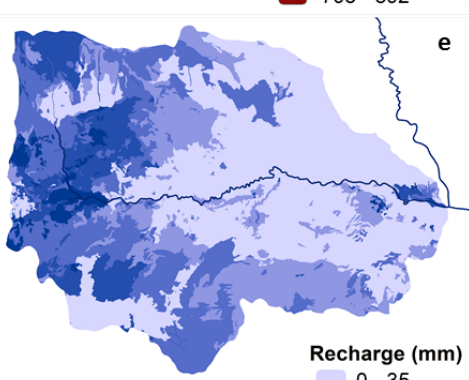

Recharge (m
$0-35$

$36-91$

$92-161$

$92-161$
$162-249$

$250-616$

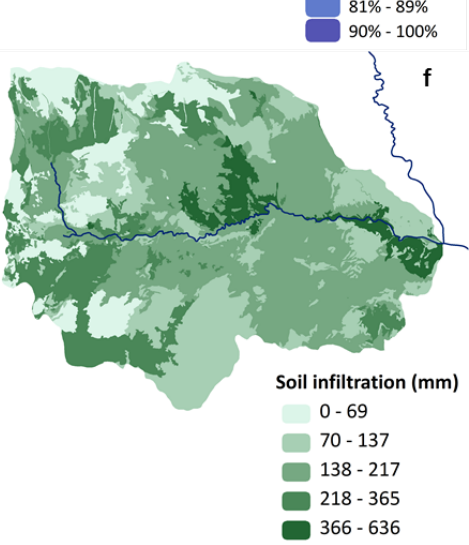

Fig. 6. Land ecosystem requirements and surface and groundwater recharge density per land use land cover (LULC) type $(\mathrm{mm})$.

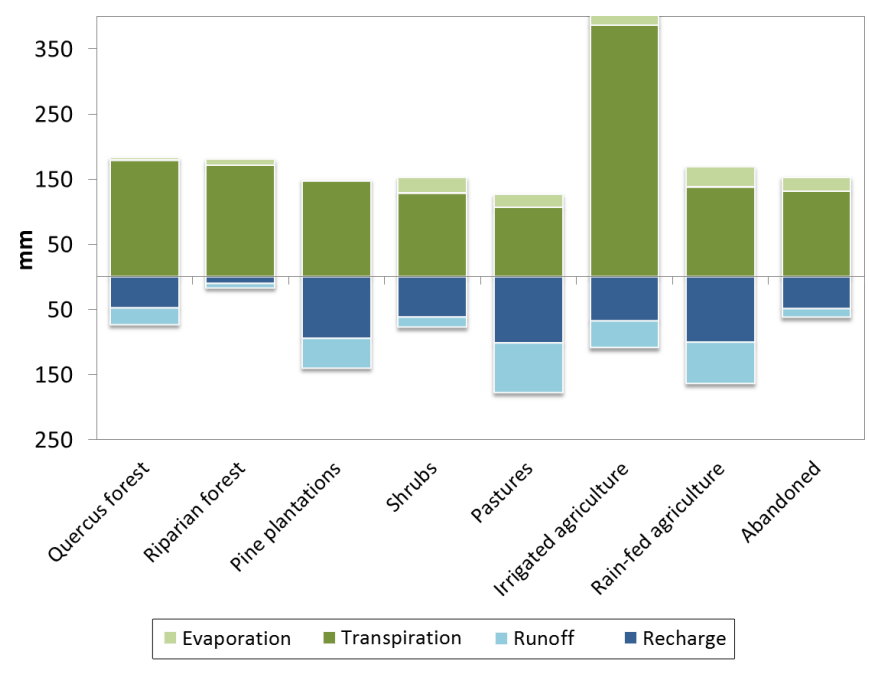

of terracing in agriculture can be detected in the rather high productivity of rain-fed agriculture as compared to similar cover vegetation like shrubs and pastures. Abandoned agricultural areas are substituted by shrubs showing a similar productivity.
Indeed, the analysis of variances showed significant differences in transpiration rates between all typologies $(p<0.05)$ except between plantations and rain-fed agriculture (both terraced), and between abandoned agricultural area shrubs and pastures. Irrigation significantly intensifies plant productivity in comparison with all other land uses. Recharge and runoff rates in this watershed are not so much determined by the land cover as they are by the geology, slope and spatial distribution of precipitation. For this reason, there are no clear statistical clusters based on LULC typologies. However, we found a significantly lower recharge rate on Quercus spp. forest compared to Pinus spp. plantations in both sierras, but no statistical difference with shrubs or pastures. Abandoned agricultural areas do not show statistical differences on their recharge rate with any other landcover type whereas both irrigation and rain-fed agriculture areas have significantly higher average recharge rates than Quercus spp. forest and shrubs.

\section{Societal metabolism (s/s-1)}

Figure 7 shows a representation of societal metabolism of the whole Upper Andarax. The human activity budget shows a low share of hours devoted to paid work activities (7\%), which have to sustain the monetary requirements for the rest of the hours $(93 \%)$. A relevant point is that unpaid work, 7 million hours, in households is higher than paid work hours, with $88 \%$ of these hours sustained by women (gender disaggregation of human activity can be found in Appendix 1). Main working activities are the services and government sectors $(50 \%)$, building $(18 \%)$, and mining and industrial activities $(9 \%)$. All of these occupy only $2 \%$ 
Fig. 7. Annual societal funds and interactions with main contexts. AG: agriculture; PW: paid work; M: millions; Mhr: million hours.

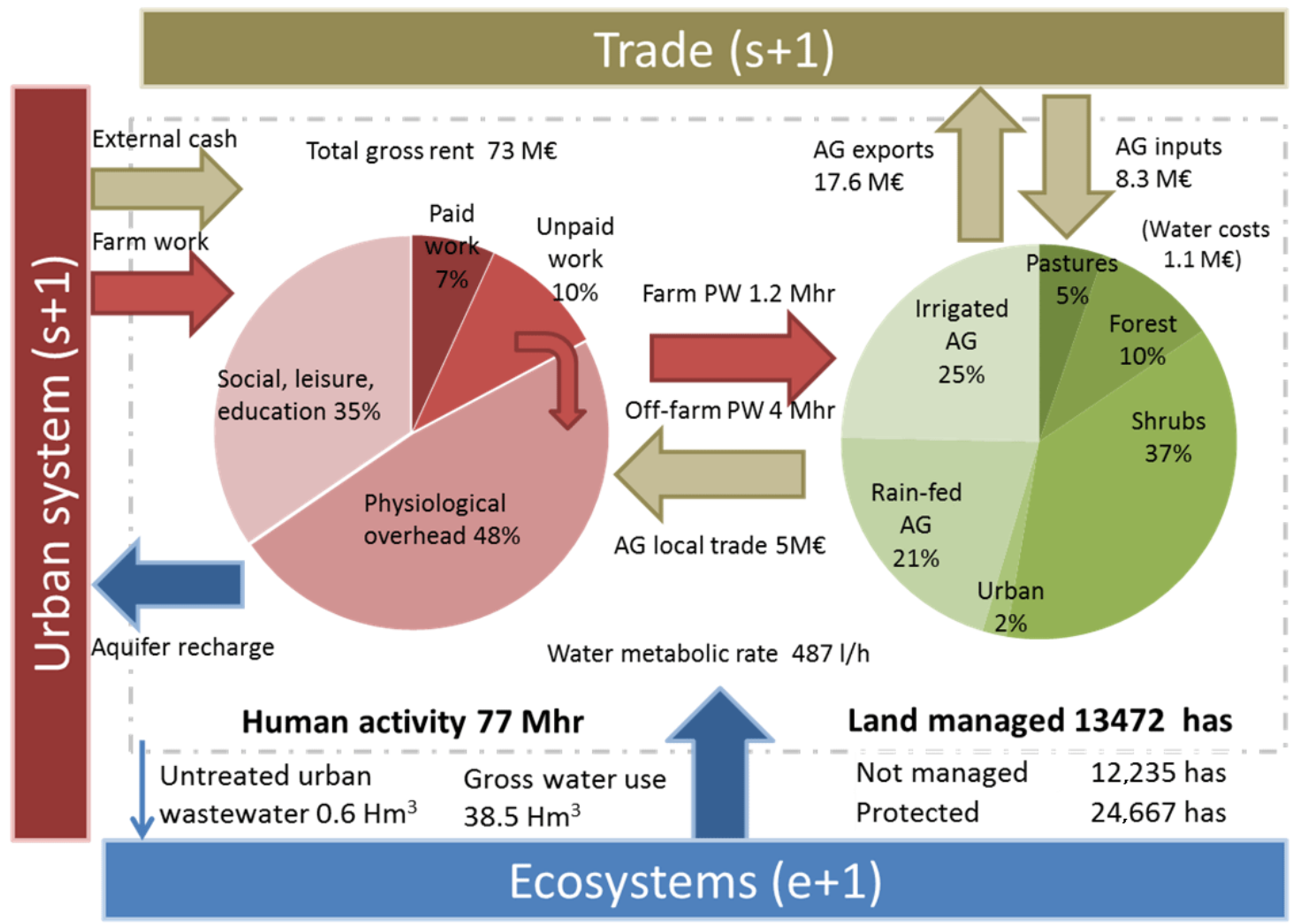

of the total land used (urban areas), whereas most of human land uses are agriculture and other extensive land-cover exploitations (grazing, forestry, and esparto gathering) accounting for $23 \%$ of formal working hours.

About $77 \%$ of the watershed's agricultural production is traded in external markets, whereas the internal market sustains $33 \%$ of revenues obtained from agricultural products. The total municipal gross rent in 2006 was 73 million Euros, indicating an important contribution of agriculture to the local economy. Water costs represent $13 \%$ of agriculture expenditures and are very low for surface water (between $1-3$ cents $€ / \mathrm{m}^{3}$ ), and more fluctuating for groundwater (between 6-18 cents $€ / \mathrm{m}^{3}$ ). The consequence of the emigration flow from the basin villages to downstream urban areas is an increasing input of working/leisure hours on weekends and the inflow of cash generated there.

The region contains a diverse pattern of rain-fed and irrigated crops, with a predominance of almond trees typically found in mountain regions in Spain because of their high adaptability to extreme conditions, i.e., poor soils, low soil moisture, and cold winters. Table 5 presents the economic and technical indicators of the different crops. As observed, irrigation substantially increases monetary productivity. The highest economic labor productivity (gross $€ /$ hour) is shown by almond production, because it is low labor intensive, followed by horticulture because of high market prices. Water transport systems are primarily "acequias" and surface flooding represents the main irrigation technique. Only citrus production at the basin outlet has introduced drip irrigation.

Table 5. Irrigated and rain-fed crops. LU = land use.

\begin{tabular}{lccccc}
\hline \hline & $\begin{array}{c}\text { LU } \\
\text { (has) }\end{array}$ & $\begin{array}{c}\text { Gross } \\
€ / \text { ha }\end{array}$ & $\begin{array}{c}\text { Gross } € / \\
\text { hr }\end{array}$ & $\begin{array}{c}\text { Use of } \\
\text { acequias }\end{array}$ & $\begin{array}{c}\text { Drip } \\
\text { irrigation }\end{array}$ \\
\hline Irrigated & & & & & \\
$\quad$ Almonds & 1100 & 6708 & 20.0 & $56 \%$ & $32 \%$ \\
Olive & 847 & 4275 & 9.9 & $84 \%$ & $15 \%$ \\
Horticulture & 661 & 7333 & 14.2 & $98 \%$ & $1 \%$ \\
$\quad$ Citrus & 634 & 4773 & 9.1 & $62 \%$ & $50 \%$ \\
Rain-fed & & & & & \\
Almonds & 1092 & 1699 & & & \\
Olive & 333 & 1549 & & & \\
$\quad$ Extensive & 326 & 176 & & & \\
Vineyards & 312 & 2504 & & & \\
\hline
\end{tabular}

\section{The ecosystems-society interface (e/i/s)}

Water exchange $(e \rightarrow s)$

Table 6 shows the water flows sustaining provisioning services in the watershed. Soil moisture use is $50 \%$ higher than water withdrawals and sustains a greater variety of extensive land uses and associated services. Because there are no major industries or 
big urban areas in the region, most of the water is used for food production. Cattle grazing also accounts for important soil water yields. Regarding the location of water withdrawals, most of the basin relies on surface water, with a special increment in the middle area for irrigation, whereas groundwater pumping concentrates in the last seven kilometers over the Low Andarax aquifer for citrus production (Fig. 8a). This change is caused by the drying out of the river whose main inflow at this point comes from urban wastewater discharges. When considering the seasonal variability (Fig. 8b), autumn and spring months are the rainiest acquiring most of the water inflow. In October, soil and aquifers refill after the summer and vegetation reaches its maximum transpiration. As observed, transpiration is almost coupled to infiltration whereas most withdrawals take place during summer to compensate soil moisture drought.

Table 6. Annual water uses in the Upper Andarax $\left(\mathrm{Hm}^{3}\right)$.

\begin{tabular}{llcc}
\hline \hline & & Withdrawn & Soil \\
\hline $\mathrm{s}$ & Gross water use & 14.2 & 21.6 \\
& Loses & 3.7 & 3.4 \\
$\mathrm{~s}-1$ & & & \\
Net uses & & 0.7 & - \\
& Urban supply & 8.8 & 8.2 \\
& Food production & - & 1.9 \\
& Forestry & - & 2.1 \\
& Esparto gathering & 0.5 & 5.8 \\
\hline Cattle & &
\end{tabular}

Fig. 8. (a) Spatial distribution of water withdrawals; (b) Seasonal distribution of water funds and flows.
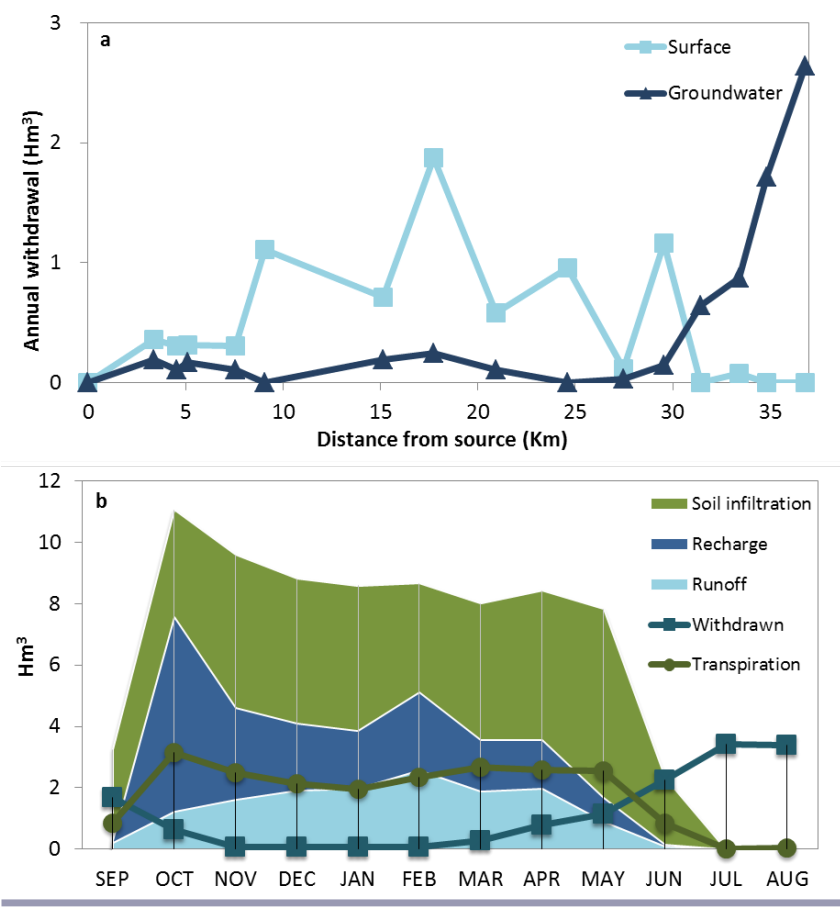

Ecosystem health $(s \rightarrow e)$

The river ecological status assessment in the RBMP considers the Alto Andarax in good status and the remaining section (Medio Andarax) in poor status. The main drivers of this poor status are the drying out of the river during the summer months because of diversion for agriculture, untreated wastewater discharge, and sediment deposition from erosion. Groundwater bodies are assessed as quantitatively and qualitatively poor status.

Figure 9 shows a clear spatial gradient on the impacts in the basin. In Alto Andarax, within the natural park, human activities are very constrained, and surface and groundwater quality meets drinkable standards (Fig. 9a). In the middle section (from $\mathrm{km}$ 10-25), main irrigation areas are located and nitrate concentrations in water increase, yet it falls within the good state category according to EUWFD reference of 6.5-9.5 mg/L (quality guidelines are gathered in Glavan et al. 2013a). Along the last 10 $\mathrm{km}$ of the Andarax River, fecal coliform concentrations are very high (up to $14,000 \mathrm{CFU} / 100 \mathrm{~mL}$ proper of untreated wastewater) and suspended solids reach $87 \mathrm{mg} / \mathrm{L}$ (EU Directive 2006/44/EC guidance level for surface waters of $\leq 25 \mathrm{mg} / \mathrm{L}$ ), making water unusable for urban and agricultural purposes. According to the Andalusian scale for regional erosion, the average annual rate of soil loss between 1992 and 2006 is deemed low (12 tn/ha yr) in $65 \%$ of the basin, moderate in $27 \%(12-50 \mathrm{tn} / \mathrm{ha} \mathrm{yr})$ and high in $9 \%$ (> $50 \mathrm{tn} / \mathrm{ha} \mathrm{yr}$ ). Highest erosion rates are found from the middle section of the basin toward the outlet, clearly overlapping marls and conglomerates areas were most agricultural and abandoned agricultural areas are located (Fig. 9c). These rates align with other studies in the region in areas with abandoned terraces (Romero and Belmonte 2008, 2009). However, they are extremely severe compared to the threshold of 1 ton/ha recommended in other parts of Europe (Verheijen et al. 2009, Glavan et al. 2013a).

Fig. 9. (a) Average annual water table change; (b) Average annual soil loss rates (c) Average groundwater water quality; (d) Average surface quality.

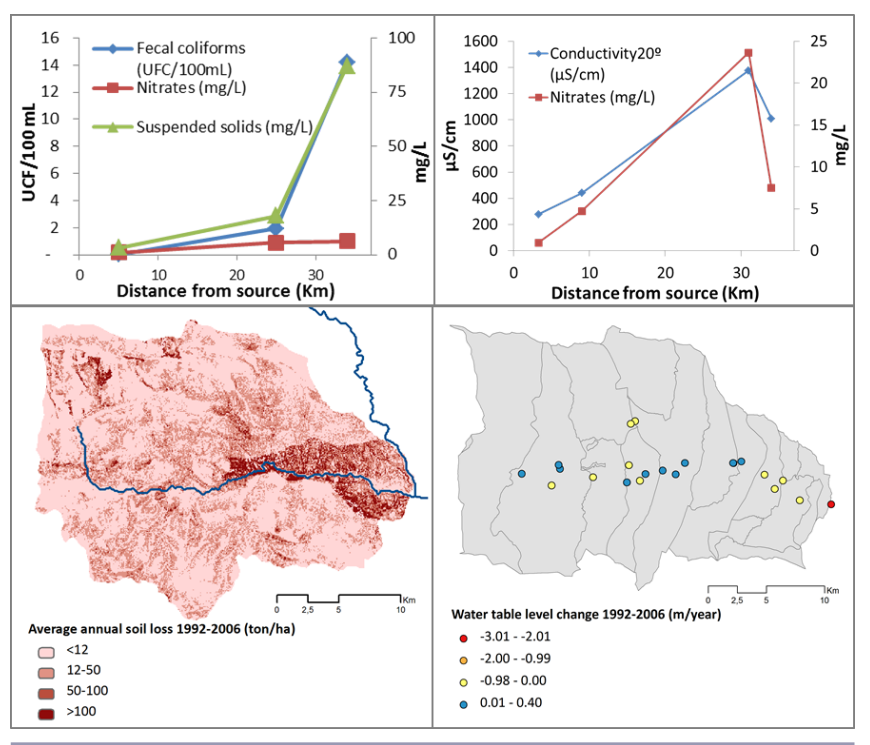


Table 7. Water demand vs availability $\left(\mathrm{Hm}^{3}\right)$.

\begin{tabular}{|c|c|c|c|c|c|c|}
\hline & \multirow[t]{2}{*}{ Withdrawals } & \multirow[t]{2}{*}{$\begin{array}{l}\text { Ecosystems } \\
\text { requirements }\end{array}$} & \multicolumn{2}{|c|}{$\begin{array}{c}\text { Water extraction } \\
\text { Index }(\%) \\
\end{array}$} & \multirow[t]{2}{*}{$\begin{array}{c}\text { Water availability } \\
\text { average year }\end{array}$} & \multirow[t]{2}{*}{ Water demand } \\
\hline & & & Average year & Dry year & & \\
\hline River & 5.8 & 2 & 0.46 & 0.67 & 3.8 & \multirow[b]{2}{*}{17.6} \\
\hline Aquifer & 7.2 & 10 & 0.34 & 0.50 & 13.2 & \\
\hline
\end{tabular}

Regarding groundwater (Fig. 9b), the Low Andarax aquifer clearly shows a higher conductivity and nitrate concentrations compared to the upper North Gador Sierra. This salinity has been related to the marl composition of the aquifer bed (SánchezMartos et al. 2005) and does not surpass the reference threshold for this type of water body in the EUWFD $(3610 \mu \mathrm{S} / \mathrm{cm})$. The nitrate peak indicates an influence of agricultural diffusive pollution even lower than the $50 \mathrm{mg} / \mathrm{L}$ threshold for groundwater poor state. Finally, water table level variations between 1992 and 2006 spatially overlap with groundwater withdrawals, decreasing in pumping areas (primarily concentrated on the Low Andarax aquifer) and increasing where the river is the major water source (Fig. 9d).

\section{Water management (e/i/s)}

In line with the ecological status assessment, both groundwater bodies have been declared as subjected to "less rigorous environmental objectives" within the RBMP, because of the complex overdraft situation created by downstream intensive greenhouse farmers. This means that they need a longer recovery horizon (beyond 2015), conditioned to the generation of additional resources through desalination in the coast. There are no aquifer restoration measures foreseen for the Upper Andarax area but new dwells are forbidden along the whole water body until regularization of existing water rights is accomplished. On the other hand, the river horizon for "good status" retrieval was set for 2015. This poses a new external constraint to the societal metabolism: impacts have to be remediated and the e-flows regime implemented on the river.

The current annual water extraction index (WEI) for the average water funds in the modeled period shows that surface water bodies are more exploited than groundwater (Table 7). When considering a drought subperiod (1976-1988), we obtain a 17\% reduction of renewable resources and a considerable increase of the annual WEI if the same water use is to be maintained. In addition, water demand is $37 \%$ higher than current water use because additional resources are claimed for irrigation. This demand can be met with available resources by substituting surface withdrawal for additional pumping, but this multiplies water costs by a factor of six. The proposed e-flows regime barely reaches $10 \%$ of runoff from October to March, but in summer months would require almost no diversion. Middle basin users who rely on surface water are those mainly affected by the e-flows implementation. The situation is totally stagnant because of the banning over new dwells and the lack of negotiation process with local irrigation communities on the proposed e-flows. This area counts the highest rates of agricultural employment and its rent per capita is low (4500-8000 € p.c.) compared to upper and downstream municipalities (8000-10,000 $€$ p.c.). Therefore, turning to groundwater or to rain-fed crops has an economic impact that needs to be further evaluated. The foreseen strategy in the RBMP to solve this conundrum is to not implement the e-flows regime until new available water resources are generated through irrigation-efficiency improvement by replacing the galleries and acequias by drip systems.

\section{DISCUSSION}

Several authors have described the alteration of the Upper Andarax hydrology through centuries of human transformations of the territory (Latorre et al 2001, Sánchez-Picón et al. 2011). Our results support these works by quantifying the increment of water availability for human productive uses, especially of soil water. Despite the importance of local wisdom on managing surface, flood, and subsurface flows, it is in soil water management that the traditional water culture of this Mediterranean region implements its more effective adaptive practices (terracing, adapted crops). Current land abandonment is perceived as a major driver of landscape change threatening this traditional system. Abandoned agricultural areas are transforming into xerophytic shrub covers, and walls of terraces are slowly eroding into the river. A key question for the maintenance of long-term water supply is the combined effect over water funds of three processes: climate change/drought periods, collapse of traditional land uses, and evolution of vegetation. Because BalanceMed does not model erosion, other eco-hydrological models like the soil and water assessment tool (SWAT) could be more suitable for further detailed estimations of the impact of agricultural abandonment on erosion rates. Other works have successfully applied this model in Mediterranean catchments to address this interaction in relation to water flows quality and quantity either on a historical basis (Glavan et al. 2013a, $b$ ) or to compare management scenarios (Glavan et al. 2012).

We not only found a marked spatial gradient on water supply and demand, but also on impacts to water bodies. The Alto Andarax contains healthy ecosystems protected by the park. Our finding of high recharge rates occurring in the low permeability soils of the upper catchment supports the reported high interaction of subsurface-surface flow in this area by Sánchez-Martos et al. (2005). As also shown by Contreras et al. (2008), the North Gador Sierra area is a key provider of water recharge to the southern part of the aquifer and plays a key role supporting intensive agriculture there. This northern part of the aquifer is affected by the assessment of "poor" ecological status of the whole aquifer that our findings contravene, i.e., water tables are not lowering and water quality does not reach poor state thresholds. The almost exclusive dependence on surface water by most upstream users limits its availability to downstream users, driving groundwater stock depletion on quantity and quality at the basin outlet. 
The societal metabolic pattern shows an intermediate situation between a low and a high external input agricultural system (Giampietro and Lomas 2014), common in high-mountain areas with multifunctional landscapes. Agricultural trade openness to external markets is important but does not sustain the whole economy because the services and public sectors are bigger in terms of employment. Our findings uncover the crucial role of unpaid women's work in households, indicating a more reproductive (functions fulfillment) than productive (market oriented) metabolic pattern. Ageing population poses a major challenge for continued viability of this pattern in the future. The adaptation strategy seems twofold: first, an increasing interaction with the urban downstream areas in terms of external revenues and agricultural land maintenance for leisure or supplementary rent; second, a sector of the population claims extending irrigation to increase agricultural productivity in line with the intensive agricultural model dominating in the surrounding geographical context. This is constrained by environmental objectives established at the water-governance level that require a reduction of water withdrawals.

The expectations generated over the possibility of obtaining additional resources through efficiency improvements might be counteracted by the effects of the progressive abandonment of the acequias. There is a feedback signal between technological and social transformations. The functioning of local irrigation communities has been inherently linked to the use and maintenance of the galleries and acequias system (Segura 2010). Their substitution by pipes and drip irrigation will permit automation thus reducing the time required for agricultural land maintenance, and at the same time, phasing out local institutional rules. In addition, there are ecological trade-offs. The declaration of the national park forced farmers to abandon acequias within park boundaries. A key consequence of this abandonment has been a decline in riparian vegetation living on their banks. This forced the park administration to maintain the acequias at considerable public cost. The question of whether it will be possible to increase productive water uses at the same time as complying with environmental objectives of the EUWFD will depend on (1) the willingness of local irrigation communities to adapt their institutional rules; and (2) whether the additional available water is allocated to meet ecosystem requirements or will generate a rebound effect, i.e., a further intensification of the saved water use. There is increasing literature (Dumont et al. 2013, Cabello and Madrid 2014, Sampedro and Del Moral 2014) showing that efficiency, so far, has not been effective in controlling water demand in the absence of proper monitoring and withdrawal control protocols.

\section{CONCLUSIONS}

Water resources research within complex systems requires conceptual devices capable of dealing with the epistemological implications of human-environment relationships. Among these are the multidimensionality of water systems, the multiple scales involved in water management, and the uncertainty over the evolution of feedback relationships within social-ecological systems. The SESWM has been proposed as a holistic framework for integrated analysis of sustainability of water resources management. This study is the first operationalization of this framework at the river-basin scale. We emphasize the importance of including the governance dimension because it is a key driver shaping human-environmental interactions. The production and evolution of hydro-social landscapes are filled by a variegated set of social agents with changing and more or less acute confrontations. The diverse and changing features of water funds and flows, together with their contentious uses, demands, and imaginaries around it, are always mediated through political institutions and policy networks and regimes, including those through which access or ownership over nature and the tools of its distribution are organized.

In the particular case of the Upper Andarax, the current water metabolism is the result of centuries of social-ecological evolution. This basin is an illustrative case of European highmountain rural areas striving to face rural exodus with an economy in transition from the agricultural to the service sector. We have shown how its societal organization is integrated within the ecosystem water metabolism and how it has influenced the eco-hydrological functioning of the basin. The observed impacts to aquatic ecosystem have some direct causes like an excess of withdrawals in dry summer periods and wastewater discharge, but also other long-term socioeconomic processes like agriculture abandonment or lack of control over extractions. From our results, we can pinpoint the following key water management challenges for the Upper Andarax: (1) the need to include soil moisture formally in water planning as the water fund providing the greatest variety of services to the social system; (2) the separation of the misleading linkage of the ecological status assessment for the North and South Gador Sierra aquifers; (3) the appropriate monitoring to ensure that efficiency improvement is a conducive strategy to meet river ecosystem requirements and additional societal demands; and finally, (4) a social-ecological approach to water governance that would require policy measures to tackle the sustainability of societal funds beyond the continuous augmentation of water flows, addressing the longterm drivers of metabolic change.

On a methodological level, we bridge the analysis of societal metabolism and ecosystem metabolism in the MuSIASEM accounting scheme on a spatially explicit basis. The analysis of ecosystem metabolism of water in river basins is proposed through the eco-hydrological processes that control water resource renewability (supply-side sustainability), the impacts caused to ecosystem health (sink-side sustainability), and the boundary concepts of water availability and ecosystem water requirements. The proposed method requires the integration of several models and multiple types of data with the associated accumulated uncertainty. We limited our eco-hydrological analysis to averaged climatic series and a snapshot of societal metabolism that is sufficient for descriptive purposes and linkage to water planning. Further steps of scenario building would require a more thorough analysis of historical trends as well as a higher temporal resolution for hydrological calibration. In addition, we focused our analysis on provision services of water but the inclusion of cultural and regulating ecosystem services is suggested for further works. Further research in the area can focus more specifically on (1) relevant linkages between land abandonment, erosion, and their impact on aquatic ecosystems; (2) efficiency improvement and its impacts on aquifer dependent systems; and (3) conflicts between local and regional scales of water governance. 
Responses to this article can be read online at: http://www.ecologyandsociety.org/issues/responses. $\mathrm{php/7778}$

\section{Acknowledgments:}

The authors are grateful to Javier Moreno for the useful information about the social-ecological history of the basin, Jesse Chakrin for his excellent editing job, and the two anonymous reviewers for their useful comments. A special thanks to Javier Martinez for sharing his incredible local wisdom and expertise, besides the most beautiful sights of the Andarax. This research has been funded by the Spanish Ministry of Science and Innovation (FPU program).

\section{LITERATURE CITED}

Allan, J. A. 1998. Virtual water: a strategic resource global solutions to regional deficits. Groundwater 36(4):545-546. http:// dx.doi.org/10.1111/j.1745-6584.1998.tb02825.x

Allen T. F. H., and T. B. Starr. 1988. Hierarchy: perspectives for ecological complexity. University of Chicago Press. Chicago, Illinois, USA.

Allen, T. F. H., and T. W. Hoekstra. 1992. Toward a unified ecology. Columbia University Press. New York, New York, USA.

Allen, T. F. H., and M. Giampietro. 2014. Holons, creaons, genons, environs, in hierarchy theory: where we have gone. Ecological Modelling 293(10):31-41. http://dx.doi.org/10.1016/j. ecolmodel.2014.06.017

Andreo, B., J. Vías, J. A. López-Geta, F. Carrasco, J. J. Durán, and P. Jiménez. 2004. Propuesta metodológica para la estimación de la recarga de acuíferos carbonáticos. Boletín Geológico y Minero 115:177-186.

Binder, C. R., J. Hinkel, P. W. G. Bots, and C. Pahl-Wostl. 2013. Comparison of frameworks for analyzing social-ecological systems. Ecology and Society 18(4): 26. http://dx.doi.org/10.5751/ es-05551-180426

Brauman, K. A., G. C. Daily, T. K. Duarte, and H. A. Mooney. 2007. The nature and value of ecosystem services: an overview highlighting hydrologic services. Annual Review of Environment and Resources 32:67-98. http://dx.doi.org/10.1146/annurev. energy.32.031306.102758

Cabello Villarejo, V, and C. Madrid López. 2014. Water use in arid rural systems and the integration of water and agricultural policies in Europe: the case of Andarax River basin. Environment, Development and Sustainability 16:957-975. http://dx.doi. org/10.1007/s10668-014-9535-8

Cohen, A., and S. Davison. 2011. An examination of the watershed approach: challenges, antecedents, and the transition from technical tool to governance unit. Water Alternatives 4:1-14.

Contreras, S., M. M. Boer, F. J. Alcalá, F. Domingo, M. Garcia, A. Pulido-Bosch, and J. Puigdefábregas. 2008. An ecohydrological modelling approach for assessing long-term recharge rates in semiarid karstic landscapes. Journal of Hydrology 351:42-57. http://dx.doi.org/10.1016/j.jhydrol.2007.11.039
Del Moral, L. 2005. La gestíon del agua en Andaluciìa: aspectos econoimicos, poliiticos y territoriales. Coleccioìn Andaluciìa XXI. Serie Economía. Mergablum, Sevilla, Spain.

Del Moral, L., and A. Do Ó. 2014. Water governance and scalar politics across multiple-boundary river basins: states, catchments and territorial powers in the Iberian Peninsula. Water International 39(3):333-347. http://dx.doi.org/10.1080/02508060.2013 .878816

De Stefano, L., J. M. Fornés, J. A. López-Geta, and F. Villarroya. 2014. Groundwater use in Spain: an overview in light of the EU Water Framework Directive. International Journal of Water Resources Development 1-17. http://dx.doi.org/10.1080/07900627.2014.938260

Dumont, A., B. Mayor, and E. López-Gunn. 2013. Is the rebound effect or Jevons Paradox a useful concept for better management of water resources? Insights from the irrigation modernisation process in Spain. Aquatic Procedia 1:64-76. http://dx.doi. org/10.1016/j.aqpro.2013.07.006

European Commission (EC). 2000. The EU Water Framework Directive. European Commission, Brussels, Belgium. [online] URL: http://ec.europa.eu/environment/water/water-framework/ index_en.html

Ewert, F., M. K. van Ittersum, T. Heckelei, O. Therond, I. Bezlepkina, and E. Andersen. 2011. Scale changes and model linking methods for integrated assessment of agri-environmental systems. Agricultural Ecosystems and Environment 142(1-2):6-17. http://dx.doi.org/10.1016/j.agee.2011.05.016

Falkenmark, M., and J. Rockström. 2004. Balancing water for humans and nature: the new approach in ecohydrology. Routledge, London, UK.

Fischer-Kowalski, M. 1998. Society's metabolism: the intellectual history of materials flow analysis, part I, 1860-1970. Journal of Industrial Ecology 2:61-78. http://dx.doi.org/10.1162/jiec.1998.2.1.61

Georgescu-Roegen, N. 1971. The entropy law and the economic process. Harvard University Press, Cambridge, Massachusetts, USA. http://dx.doi.org/10.4159/harvard.9780674281653

Giampietro, M. 2003. Multi-scale integrated analysis of agroecosystems. CRC Press, Boca Raton, Florida, USA.

Giampietro, M., R. J. Aspinall, J. Ramos-Martin, and S. G. F. Bukkens. 2014. Resource accounting for sustainability assessment: the nexus between energy, food, water and land use. Routledge, New York, New York, USA.

Giampietro, M., and P. Lomas. 2014. The interface between societal and ecosystem metabolism. Page 33-48 in M. Giampietro, R. J. Aspinall, J. Ramos-Martin, and S. G. F. Bukkens, editors. Resource accounting for sustainability assessment: the nexus between energy, food, water and land use. Routledge, New York, New York, USA.

Giampietro, M., K. Mayumi, and J. Ramos-Martin. 2009. Multiscale integrated analysis of societal and ecosystem metabolism (MuSIASEM): theoretical concepts and basic rationale. Energy 34:313-322. http://dx.doi.org/10.1016/j.energy.2008.07.020

Giampietro, M., K. Mayumi, and A. H. Sorman. 2011. The metabolic pattern of societies: where economists fall short. Routledge, New York, New York, USA. 
Glavan, M., S. M. White, and I. P. Holman. 2012. Water quality targets and maintenance of valued landscape character experience in the Axe catchment, UK. Journal of Environmental Management 103:142-153. http://dx.doi.org/10.1016/j. jenvman.2012.03.009

Glavan, M., V. Milicic, and M. Pintar. 2013a. Finding options to improve catchment water quality: lessons learned from historical land use situations in a Mediterranean catchment in Slovenia. Ecological Modelling 261:58-73. http://dx.doi.org/10.1016/j. ecolmodel.2013.04.004

Glavan, M., M. Pintar, and M. Volk. 2013b. Land use change in a 200-year period and its effect on blue and green water flow in two Slovenian Mediterranean catchments - lessons for the future. Hydrological Processes 27:3964-3980. http://dx.doi.org/10.1002/ hyp. 9540

Gupta, J., and C. Pahl-Wostl. 2013. Global water governance in the context of global and multilevel governance: its need, form, and challenges. Ecology and Society 18(4): 54. http://dx.doi. org/10.5751/es-05952-180453

Henriques, C., I. P. Holman, E. Audsley, and K. Pearn. 2008. An interactive multi-scale integrated assessment of future regional water availability for agricultural irrigation in East Anglia and North West England. Climate Change 90:89-111. http://dx.doi. org/10.1007/s10584-008-9459-0

Hoekstra, A. Y., and A. K. Chapagain. 2006. Water footprints of nations: water use by people as a function of their consumption pattern. Water Resources Management 21(1):35-48. http://dx.doi. org/10.1007/s11269-006-9039-X

Hoekstra, A. Y., M. M. Mekonnen, A. K. Chapagain, R. E. Mathews, and B. D. Richter. 2012. Global monthly water scarcity: blue water footprints versus blue water availability. PLOS ONE 7. http://dx.doi.org/10.1371/journal.pone.0032688

Instituto Nacional de Estadística (INE). 2011. National population and housing census. Instituto Nacional de Estadística, Madrid, Spain. [online] URL: http://www.ine.es/censos2011 datos/ cen 11 datos inicio.htm

Jakeman, A. J., and R. A. Letcher. 2003. Integrated assessment and modelling: features, principles and examples for catchment management. Environmental Modelling and Software 18:491-501. http://dx.doi.org/10.1016/S1364-8152(03)00024-0

Janssen, M. A., Ö. Bodin, J. M. Anderies, T. Elmqvist, H. Ernstson, R. R. J. McAllister, P. Olsson, and P. Ryan. 2006. Toward a network perspective of the study of resilience in socialecological systems. Ecology and Society 11(1): 15. [online] URL: http://www.ecologyandsociety.org/vol11/iss1/art15/

Jørgensen, S. E., and S. N. Nielsen. 2013. The properties of the ecological hierarchy and their application as ecological indicators. Ecological Indicators 28:48-53. http://dx.doi.org/10.1016/j. ecolind.2012.04.010

Koestler, A. 1969. Beyond atomism and holism: the concept of the holon. Pages 192-232 in A. Koestler and J. R. Smythies, editors. Beyond reductionism: new perspectives in the life sciences.. Hutchinson, London, UK.

Latorre, J. G., J. García-Latorre, and A. Sanchez-Picón. 2001. Dealing with aridity: socio-economic structures and environmental changes in an arid Mediterranean region. Land Use Policy 18:53-64. http://dx.doi.org/10.1016/S0264-8377(00)00045-4

Letcher, R. A., B. F. W. Croke, and A. J. Jakeman. 2007. Integrated assessment modelling for water resource allocation and management: a generalised conceptual framework. Environmental Modelling and Software 22:733-742. http://dx.doi.org/10.1016/j. envsoft.2005.12.014

Li, N., and L. Ren. 2010. Application and assessment of a multiscale data integration method to saturated hydraulic conductivity in soil. Water Resources Research 46:W09510. http:// dx.doi.org/10.1029/2009wr008645

Liu, J., T. Dietz, S. R. Carpenter, M. Alberti, C. Folke, E. Moran, A. N. Pell, P. Deadman, T. Kratz, J. Lubchenco, E. Ostrom, Z. Ouyang, W. Provencher, C. L. Redman, S. H. Schneider, and W. W. Taylor. 2007. Complexity of coupled human and natural systems. Science 317:1513-1516. http://dx.doi.org/10.1126/ science. 1144004

Liu, Y., H. Gupta, E. Springer, and T. Wagener. 2008. Linking science with environmental decision making: experiences from an integrated modeling approach to supporting sustainable water resources management. Environmental Modelling and Software 23:846-858. http://dx.doi.org/10.1016/j.envsoft.2007.10.007

MacLachlan, S. P., and J. D. Moulton. 2006. Multilevel upscaling through variational coarsening. Water Resources Research 42: W02418. http://dx.doi.org/10.1029/2005wr003940

Madrid, C., V. Cabello, and M. Giampietro. 2013. Water-use sustainability in socioecological systems: a multiscale integrated approach. Bioscience 63:14-24.

Madrid, C., and M. Giampietro. 2014. The water grammar. Pages 116-134 in M. Giampietro, R. J. Aspinall, J. Ramos-Martin, and S. G. F. Bukkens, editors. Resource accounting for sustainability assessment: the nexus between energy, food, water and land use. Routledge, New York, New York, USA.

Madrid, C., and M. Giampietro. 2015. The water metabolism of socio-ecological systems: reflections and a conceptual framework. Journal of Industrial Ecology (In press).

Martínez, J. D. S., E. A. Jiménez, J. M. Guerrero, and A. G. Almonacid. 2008. La repoblación forestal de Sierra Morena, Jaén, (1940-1984). Anales de Geografía de la Universidad Complutense 28:105-131.

Martínez, M., and S. Usero, editors. 2010. Río Andarax. Agencia Andaluza del Agua. Consejería de Medio Ambiente. Junta de Andalucía, Seville, Spain. [online] URL: http://www. juntadeandalucia.es/medioambiente/portal web/

agencia_andaluza_del_agua/participacion/publicaciones/rio_andarax. pdf

Mateo Callejón, S. 2013. El modelo de horticultura intensiva de Almería ante la crisis actual. Una visión desde las modernas teorías del crecimiento económico. Cajamar Caja Rural, Almería, Spain. [online] URL: http://www.publicacionescajamar.es/series-tematicas/ economia/el-modelo-de-horticultura-intensiva-de-almeria-ante-lacrisis-actual-una-vision-desde-las-modernas-teorias-del-crecimientoeconomico/ 
Menzel, L., and A. Matovelle. 2010. Current state and future development of blue water availability and blue water demand: a view at seven case studies. Journal of Hydrology 384:245-263. http://dx.doi.org/10.1016/j.jhydrol.2010.02.018

Ministerio de Medio Ambiente, Medio Rural y Marino (MARM). 2008. Instrucción de planificación hidrológica. ORDEN ARM/2656/2008. Ministerio de Medio Ambiente, Medio Rural y Marino, Madrid, Spain. [online] URL: http:// www.sghn.org/Normativa ambiental/Auga Humidais/ Orden ARM 26562008 Instruccion Planificacion Hidrologica. pdf

Mix, K., V. L., Lopes, and W. Rast. 2015. A systems approach to understanding the evolution of the agro-social-ecological system of the Upper Rio Grande-San Luis Valley, Colorado. Water Resources Management 29(2):233-251. http://dx.doi.org/10.1007/ $\underline{\text { s11269-014-0735-7 }}$

Molden, D., M. Vithanage, C. de Fraiture, J. M. Faures, L. Gordon, F. Molle, and D. Peden. 2011. Water availability and its use in agriculture. Pages 707-732 in P. Wilderer, editor. Treatise on water science. Elsevier, Atlanta, Georgia, USA. http://dx.doi. org/10.1016/b978-0-444-53199-5.00108-1

Molle, F., and P. Mollinga. 2003. Water poverty indicators: conceptual problems and policy issues. Water Policy 5:529-544.

Ostrom, E. 2009. A general framework for analyzing sustainability of social-ecological systems. Science 325:419-422. http://dx.doi.org/10.1126/science.1172133

Padowski, J. C., and J. W. Jawitz. 2012. Water availability and vulnerability of 225 large cities in the United States. Water Resources Research 48(12):1944-1973. http://dx.doi. org/10.1029/2012WR012335

Pahl-Wostl, C., G. Holtz, B. Kastens, and C. Knieper. 2010. Analyzing complex water governance regimes: the management and transition framework. Environmental Science and Policy 13:571-581. http://dx.doi.org/10.1016/j.envsci.2010.08.006

Pahl-Wostl, C., L. Lebel, C. Knieper, and E. Nikitina. 2012. From applying panaceas to mastering complexity: toward adaptive water governance in river basins. Environmental Science and Policy 23:24-34. http://dx.doi.org/10.1016/j.envsci.2012.07.014

Parish, E. S., E. Kodra, K. Steinhaeuser, and A. R. Ganguly. 2012. Estimating future global per capita water availability based on changes in climate and population. Computer and Geosciences 42:79-86. http://dx.doi.org/10.1016/j.cageo.2012.01.019

Pattee H. H. 1973. Hierarchy theory: the challenge of complex systems. Braziller, New York, New York, USA.

Poff, N. L., B. D. Richter, A. H. Aarthington, S. E. Bunn, R. J. Naiman, E. Kendy., M. Acreman, C. Apse, B. P. Bledsoe, M. C. Freeman, J. Henriksen, R. B. Jacobson, J. G. Kennen, D. M. Merritt, J. H. O'Keeffe., J. D. Olden, K. Rogers, R. E. Tharme, and A. Warner. 2010. The ecological limits of hydrologic alteration (ELOHA): a new framework for developing regional environmental flow standards. Freshwater Biology 55(1):147-170. http://dx.doi.org/10.1111/j.1365-2427.2009.02204.x

Post, D. A., F. H. S. Chiew, J. Teng, N. R. Viney, F. L. N. Ling, G. Harrington, R. S. Crosbie, B. Graham, S. Marvanek, and R.
McLoughlin. 2012. A robust methodology for conducting largescale assessments of current and future water availability and use: a case study in Tasmania, Australia. Journal of Hydrology 412-413:233-245. http://dx.doi.org/10.1016/j.jhydrol.2011.02.011

Pulido-Bosch, A., and Y. B. Sbih. 1995. Centuries of artificial recharge on the southern edge of the Sierra Nevada (Granada, Spain). Environmental Geology 26:57-63. http://dx.doi.org/10.1007/ $\underline{\mathrm{BF} 00776033}$

Rathwell, K. J., and G. D. Peterson. 2012. Connecting social networks with ecosystem services for watershed governance: a social-ecological network perspective highlights the critical role of bridging organizations. Ecology and Society 17(2): 24. http:// dx.doi.org/10.5751/es-04810-170224

Romero, A., and F. Belmonte 2008. Erosión en forestaciones aterrazadas en medios semiáridos: región de Murcia. Editum, Universidad de Murcia, Murcia, Spain.

Romero, A., and F. L. Bermudez. 2009. Soil erosion and desertification in neogene-quaternary basins of the region of Murcia. Fundación Instituto Euromediterráneo del Agua (IEA), Murcia, Spain.

Sampedro, D., and L. Del Moral. 2014. Tres décadas de política de aguas en Andalucía. Cuadernos Geográficos 53(1):36-67. [online] URL: $\underline{\text { http://www.redalyc.org/pdf/171/17131186002.pdf }}$

Sánchez-Martos, F., A. Pulido-Bosch, A. Vallejo, J. Gisbert, and L. Molina. 2005. Hydrogeochemical aspects about the interaction groundwater-surface water in the Andarax River (Almería). Geogaceta 37:91-94.

Sánchez-Martos, F., G. Benito, J. Casas-Casas, I. FrancesHerrera, J. Gisbert-Gallego, L. Molina-Sanchez, A. PulidoBosch, A. Vallejos-Izquierdo, and A. Zapata-Sierra. 2013. Caracterizacón y evaluación de los factores hidrogeológicos, hidrológicos y antrópicos que condicionan la dependencia aguas superficiales-subterraneas en el río Andarax (Almeria). Conference proceedings: X Simposio en Hidrogeología. Instituto Geológico y Minero Español. Granada, Spain.

Sánchez-Picón, A., J. A. Aznar-Sánchez, and J. García-Latorre. 2011. Economic cycles and environmental crisis in arid southeastern Spain. A historical perspective. Journal of Arid Environments 75:1360-1367.

Scholz, R. W., and C. R. Binder. 2003. The paradigm of humanenvironment systems. Working Paper 37. Natural and Social Science Interface. Swiss Federal Institute of Technology, Zürich, Switzerland.

Serrano-Tovar, T., and M. Giampietro. 2014. Multi-scale integrated analysis of rural Laos: studying metabolic patterns of land uses across different levels and scales. Land Use Policy 36:155-170. http://dx.doi.org/10.1016/j.landusepol.2013.08.003

Segura, D. 2010. Usos y aprovechamientos tradicionales del agua. Pages 249-256 in M. Martinez and S. Usero, editors. Río Andarax. Agencia Andaluza del Agua. Consejería de Medio Ambiente. Junta de Andalucía, Seville, Spain.

Swyngedouw, E. 2006. Circulations and metabolisms: (hybrid) natures and (cyborg) cities. Science as Culture 15(2):105-121. http://dx.doi.org/10.1080/09505430600707970 
Verheijen, F. G. A., R. J. A. Jones, R. J. Rickson, and C. J. Smith. 2009. Tolerable versus actual soil erosion rates in Europe. EarthScience Reviews 94:23-38. http://dx.doi.org/10.1016/j.

earscirev.2009.02.003

Vörösmarty, C. J., C. Pahl-Wostl, and A. Bhaduri. 2013. Water in the anthropocene: new perspectives for global sustainability. Current Opinion in Environmental Sustainability. 5:535-538. http:// dx.doi.org/10.1016/j.cosust.2013.11.011

Willaarts, B. A., M. Volk, and P. A. Aguilera. 2012. Assessing the ecosystem services supplied by freshwater flows in Mediterranean agroecosystems. Agricultural Water Management 105:21-31. http://dx.doi.org/10.1016/j.agwat.2011.12.019

Zhou, Y. 2009. A critical review of groundwater budget myth, safe yield and sustainability. Journal of Hydrology 370:207-213. http:// dx.doi.org/10.1016/j.jhydrol.2009.03.009 


\section{Appendix 1}

This appendix has the purpose of extending the methodological description including detailed calculation of variables and modeling validation.

\section{Scales}

Even though watersheds are the object of study of hydrology par excellence, they are not in societal metabolism of water. One of the main reasons is the scale mismatch on available data. Economic variables are crucial to study the self-organization of social systems. These are not usually available at the exact boundaries of a catchment and have either to be aggregated from lower administrative divisions (municipalities or similar), or disaggregated from upper ones. Focusing on the watershed level we gain connection with eco-hydrological processes and water governance but we lose the capacity to delve in the economic relations within the social system. To this purpose, administrative units are more appropriate as analytical extent (see for instance Madrid et al. 2014).

Agriculture is commonly the main water consumer in a river basin and the societal metabolism approach to agro-ecosystems is the rural systems analysis (Ravera et al. 2014, Serrano and Giampietro 2014). It focuses on the allocation of land and human activity in terms of time use of rural households and the associated production and consumption of biophysical and monetary flows (Scheidel 2013). These studies are usually carried out at local scales, gathering data and building metabolic typologies on a bottom up basis through surveys to farmers and households. The size of a river basin and the necessary consideration of urban water require coarser modeling resolutions.

River basins are always middle scales, between the social and hydrological, between the local and the regional, between the rural and the urban. Allen and Hoekstra, 1992:64 shed light on the problematic with middle scales: "these have too many parts to model each one separately, but not enough to allow averages that fully subsume the individuality of the part. Questions that cannot be answered imply a middle number system specification. They are unpredictable because the constraint structure is unreliable. [...] At middle scales, each part of the landscape has its own individual explanation". The multi-axes holarchic representation (Figure $2 b$ of the paper) is an attempt to escape this middle scales dialectic. Any holon results from the composition between the observed system and the observer interests. We set the organizational levels for our system, and with them the relevant parts of the system that we want to observe. There is a tendency to augment the size of the system and thus its spatial extent with the level, but holons can be analyzed at any temporal and spatial scale (we can study a rock holding it with our hand or looking through a microscope). Main constraints are data availability and modelling capacity.

Figure 1 shows the temporal and spatial levels used for the Upper Andarax grammar according to these constraints. We run the BalanceMED model on temporal monthly and spatial Hydrological Units (HU) resolutions. Results were aggregated to the extents of one year and land uses and covers types. Socioeconomic data are available for a variety of grains (see Table 1). Human activity is mapped for whole urban areas (municipal level) and agricultural land uses for irrigation 
communities and rain-fed agriculture polygons. Note that we could do a municipal level analysis (comparing each municipality Land-Human activity budgets) but this would enlarge the amount of results and loose the purpose of the study: the operationalization of the SESWM framework for the analysis of water management at river basin scale. As Schneiel 2013 explains "every kind of data collection is always a 'heroic simplification' of a complex rural system and the issue is rather to find the adequate simplification, which allows answering some relevant research question". A more detailed hydrological resolution and, especially, temporal series of water use would clearly improve the method analytical potential.

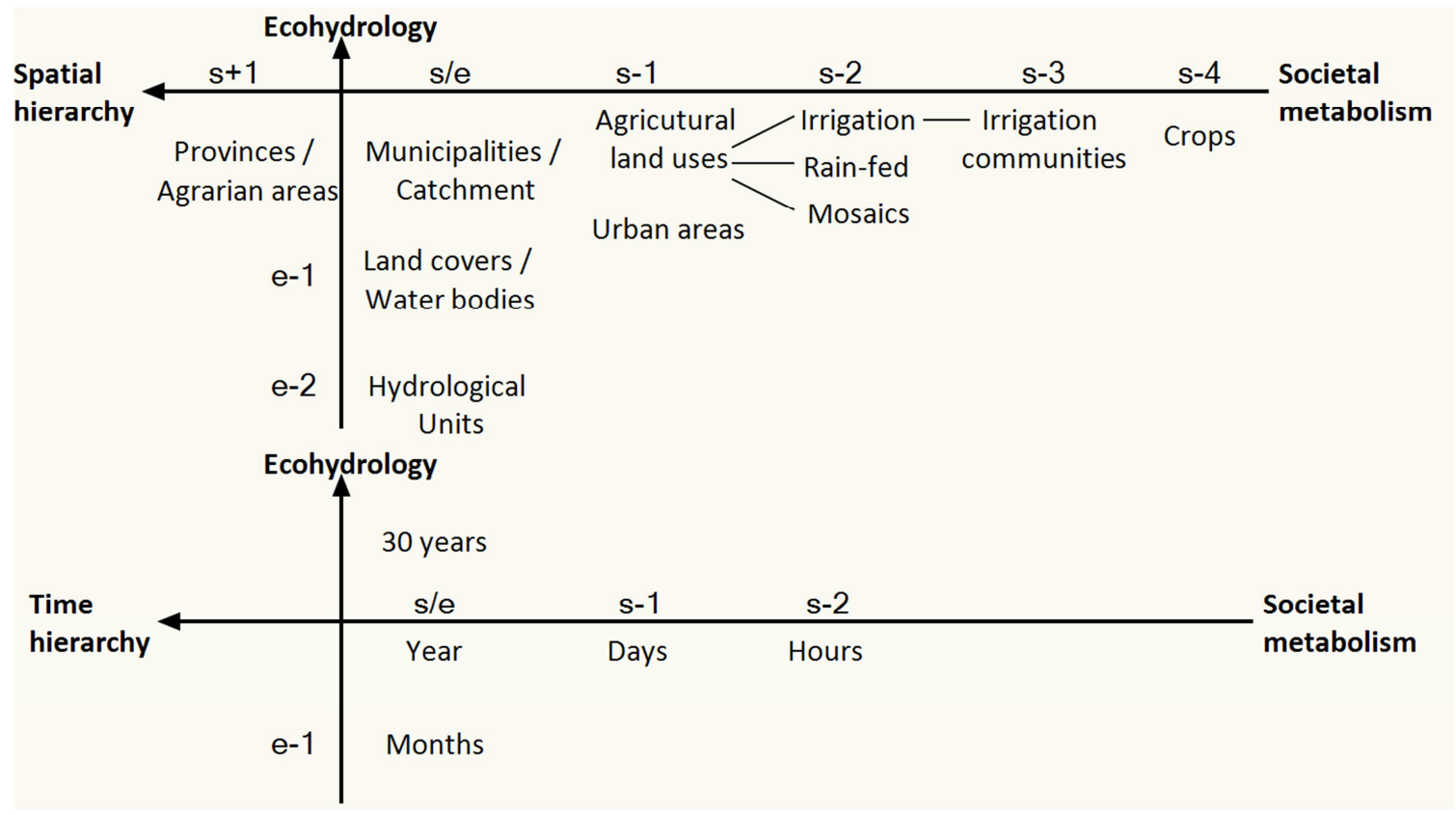

Figure 1- Temporal and spatial hierarchies in the Upper Andarax water grammar

\section{Conceptual model and formal categories}

The conceptual model for variables calculation is presented in Figure 2 and the formal categories of the grammar in Table 1. Codes and databases can be downloaded here:

https://www.dropbox.com/sh/45za6hqmnjelqoi/AAD-ObuilYtGzFwVKyJ WzQ5a?dl=0 


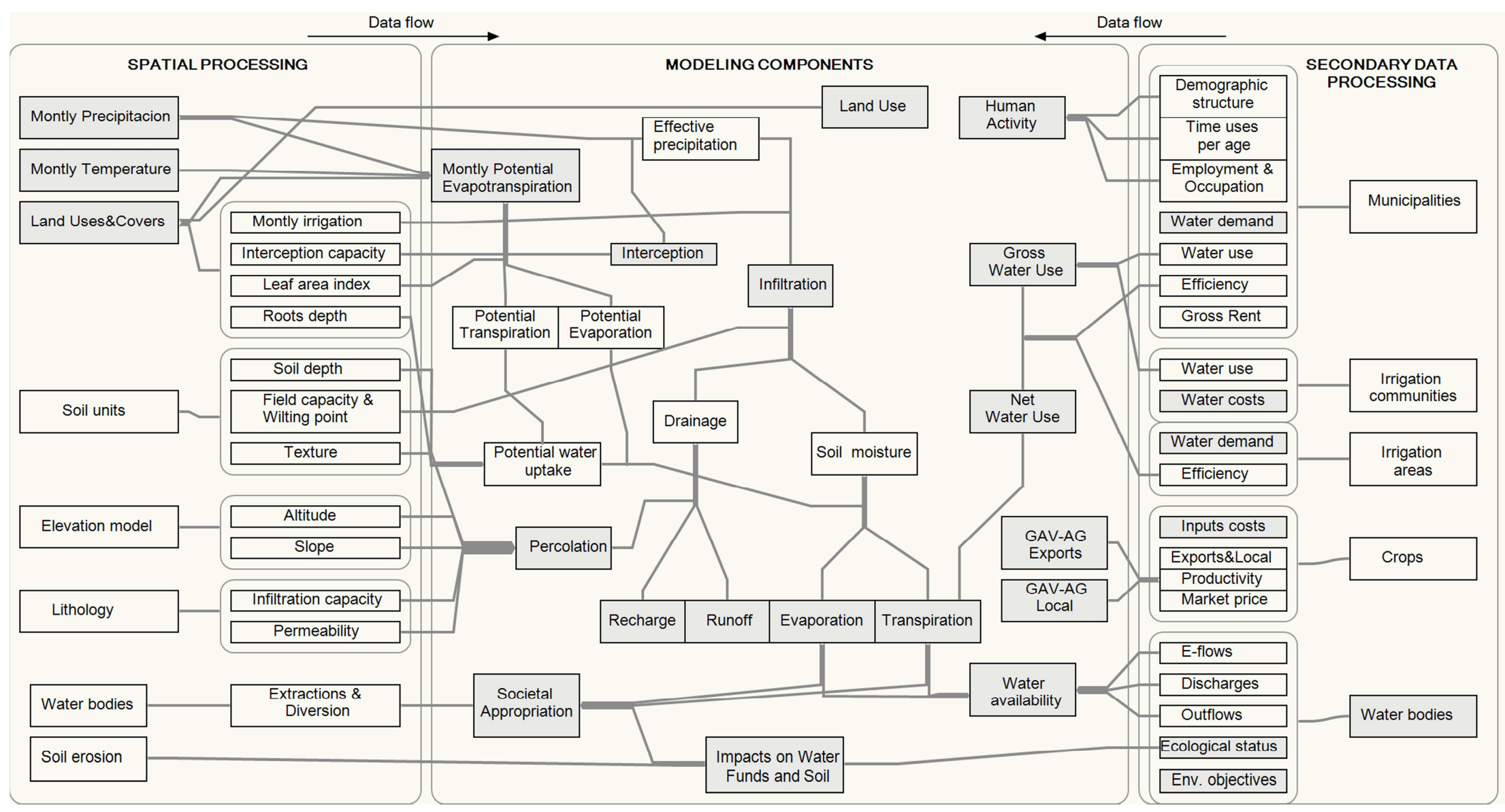

Figure $\mathbf{2}$ - Conceptual scheme for water grammar formalization 
Table 1- Formal categories of the water grammar

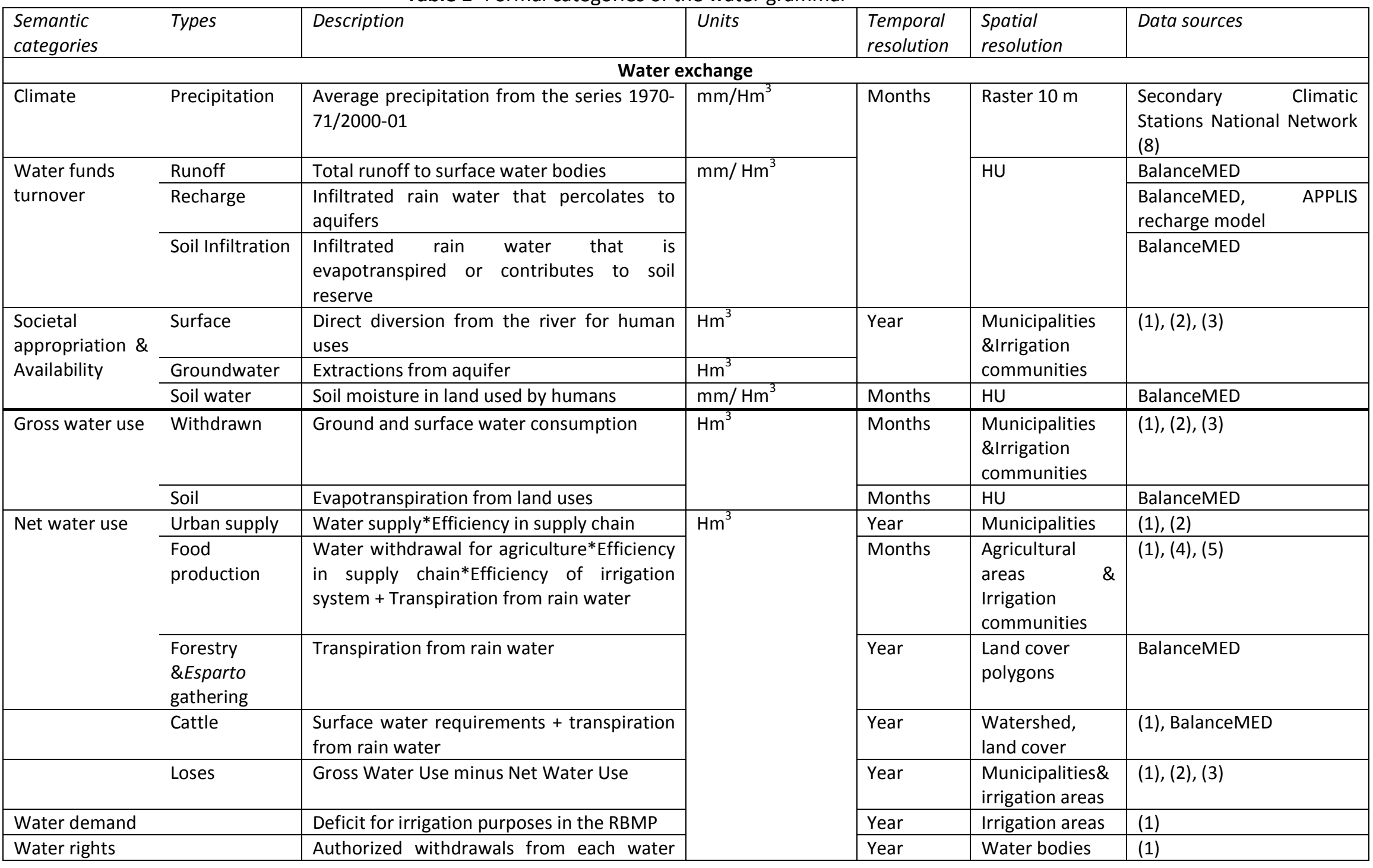




\begin{tabular}{|c|c|c|c|c|c|c|}
\hline & & body & & & & \\
\hline \multicolumn{7}{|c|}{$\begin{array}{ll} & \text { Organization } \\
\end{array}$} \\
\hline Climate & Temperature & $\begin{array}{l}\text { Average precipitation from the series 1970- } \\
2001\end{array}$ & oC & Months & Raster $10 \mathrm{~m}$ & $\begin{array}{l}\text { Secondary Climatic } \\
\text { Stations Network (8) }\end{array}$ \\
\hline \multirow[t]{2}{*}{ Water bodies } & Rivers & Descriptive category: water bodies types & - & 6 years & 6 years & \multirow[t]{2}{*}{$(1)$} \\
\hline & Aquifers & considered in the RBMP & & & & \\
\hline \multicolumn{2}{|l|}{ Land covers } & Surface occupied by land cover types & Hectares & 4 years & $\begin{array}{l}\text { Land cover } \\
\text { polygons }\end{array}$ & \multirow{2}{*}{$\begin{array}{l}\text { Map of Land Uses and } \\
\text { Covers of Andalusia } 2003 \\
\text { (9) }\end{array}$} \\
\hline $\begin{array}{l}\text { Managed land } \\
\text { uses }\end{array}$ & & $\begin{array}{l}\text { Surface occupied by land uses types under } \\
\text { managed land }\end{array}$ & Hectares & 4 years & $\begin{array}{l}\text { Land use } \\
\text { polygons }\end{array}$ & \\
\hline \multirow[t]{4}{*}{ Human activity } & $\begin{array}{l}\text { Physiological } \\
\text { overhead }\end{array}$ & $\begin{array}{l}\text { Hours devoted to personal care, eating, } \\
\text { sleeping and dependent people time }\end{array}$ & \multirow[t]{4}{*}{ Hours } & \multirow[t]{4}{*}{ Hours } & \multirow[t]{4}{*}{ Municipalities } & \multirow{4}{*}{$\begin{array}{l}\text { Time Use Survey of } \\
\text { Almeria province 2002/03 } \\
(10) \\
\text { Spanish Population and } \\
\text { Households Census 2001 } \\
(11) \\
\text { Local population census } \\
2005 \text { and } 2011(10)\end{array}$} \\
\hline & $\begin{array}{l}\text { Social, Leisure } \\
\text { \&Education }\end{array}$ & $\begin{array}{l}\text { Hours devoted to traveling, leisure } \\
\text { activities, education and volunteering }\end{array}$ & & & & \\
\hline & Unpaid work & Hours devoted to households work & & & & \\
\hline & Paid Work & $\begin{array}{l}\text { Hours devoted to each type of paid work } \\
\text { sector by the working population }\end{array}$ & & & & \\
\hline \multirow[t]{2}{*}{$\begin{array}{l}\text { Technical } \\
\text { capital }\end{array}$} & $\begin{array}{l}\text { Hydraulic } \\
\text { infrastructures }\end{array}$ & $\begin{array}{l}\% \text { of surface of irrigation communities } \\
\text { supplied by acequias }\end{array}$ & \multirow[t]{2}{*}{$\%$} & \multirow[t]{4}{*}{ Year } & \multirow[t]{2}{*}{ Crop types } & 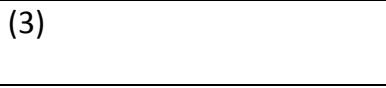 \\
\hline & $\begin{array}{l}\text { Irrigation } \\
\text { technology }\end{array}$ & $\begin{array}{l}\% \text { of surface of irrigation communities with } \\
\text { drip irrigation }\end{array}$ & & & & (3) \\
\hline \multirow[t]{2}{*}{$\begin{array}{l}\text { Monetary } \\
\text { exchange }\end{array}$} & $\begin{array}{l}\text { Agricultural } \\
\text { inputs\& Water } \\
\text { costs }\end{array}$ & $\begin{array}{l}\text { Total expenditures of irrigated agriculture } \\
\text { on water and other inputs }\end{array}$ & \multirow[t]{2}{*}{$€$} & & $\begin{array}{l}\text { Crops types \& } \\
\text { Irrigation } \\
\text { communities }\end{array}$ & (3), (7) \\
\hline & $\begin{array}{l}\text { Gross Added } \\
\text { Value }\end{array}$ & $\begin{array}{l}\text { Total income from local and external } \\
\text { markets }\end{array}$ & & & Crops types & (3), (6) \\
\hline
\end{tabular}

(1) CMAT 2012. Andalusia Mediterranean River Basins Management Plan 2009-2015. [online] URL:

http://www.juntadeandalucia.es/medioambiente/site/portalweb/menuitem.7e1cf46ddf59bb227a9ebe205510e1ca/?vgnextoid=6d3173f 2c746a310VgnVCM2000000624e50aRCRD\&vgnextchannel=0bb66af68bb96310VgnVCM1000001325e50aRCRD

(2) Martinez, J. 2011. Energy Footprint of the urban water supply in Almeria province.

(3) CA 2008. Inventory and characterization of irrigation in Andalusia. [online] URL: 
http://www.juntadeandalucia.es/agriculturaypesca/sigregadios/servlet/regadios

(4) Fundación Cajamar. 2004. Irrigation doses for intensive horticulture in Almeria.[online] URL: http://www.publicacionescajamar.es/seriestematicas/centros-experimentales-las-palmerillas/

(5) CA 2011. System of technical assistance to farmers of the Andalusian government. [online] URL:

http://www.juntadeandalucia.es/agriculturaypesca/ifapa/sar

(6) CMAT 2006. Andalusia Multiterritorial Information System. [online] URL:

http://www.juntadeandalucia.es/institutodeestadisticaycartografia/sima/index2.htm

(7) CA 2005. Annual statistics on agriculture and fishing of Andalusia. [online] URL:

http://www.juntadeandalucia.es/agriculturaypesca/portal/servicios/estadisticas/estadisticas/agrarias/resumen-anual.html

(8) AEMET. Spanish State Agency of Meteorology. [online under payment] URL: http://www.aemet.es/es/serviciosclimaticos/datosclimatologicos

(9) REDIAM. Andalusian Network for Environmental Information. [online] URL: http://www.juntadeandalucia.es/medioambiente/site/rediam

(10) IECA. Andalusian Statistical and Cartography Office. [online] URL: http://www.juntadeandalucia.es/institutodeestadisticaycartografia

(11) INE. Spanish Statistical Office. [online] URL: http://www.ine.es/jaxi/menu.do?type=pcaxis\&path=\%2Ft20\%2Fe242\&file=inebase\&L=0 


\section{BalanceMED}

\section{Precipitation and potential evapotranspiration}

GIS raster layers of average monthly precipitation and potential evapotranspiration (PE) variables were obtained from the Andalusian Network for Environmental Information (REDIAM) for the period 1971-2000. Monthly scale reflects better the normal Mediterranean environmental conditions due to the usual lack of rainfall in finer time scales generated by long periods of water deficit. This source of information was chosen because it is the same used by the River Basin Authority for hydrological modeling. We found hydrological variables (runoff and recharge) were greatly overestimated using this data source. Mean values are usually not representative when dealing with very irregular regimes with skewed precipitation density functions such as the ones in the Andarax. In arid and semiarid climates, the median as central statistic measure is more robust. For this reason, median monthly values of were obtained at the closer 24 meteorological stations with available data for the 1971-2000 period (within a buffer of $10 \mathrm{~km}$ ). These stations belong to the Spanish State Agency of Meteorology and only provide temperature and rainfall data. PE was estimated using an excel macro based on Thornthwaite method (HydroBio3, Camara and Martinez 2002). All data series where then spatialized using the Inverse Weighted Distance interpolation in ArcGIS 10.2 to obtain continuous information to be entered in the model. Results significantly improved making estimates closer to real conditions.

\section{Hydrological units processing}

Hydrological units are obtained from the intersection of soil and land cover GIS layers. Previously, several parameters were calculated for each of them. Roots depth, Leaf Area Index and interception capacity were gathered for vegetation species through literature review. Weighted means per number of species were obtained for each land cover unit. Soil parameters are wilting point, field capacity and soil depth. These are calculated from data on lime, clay and organic matter fractions extracted from the soil cartography of the Desertification Prevention in the Mediterranean Project (LUCDEME) of the Spanish Ministry of Agriculture.

\section{Percolation}

The APLIS equation was proposed by Andreo et al. 2004 for determining the average rate of recharge in carbonate aquifers. This rate is expressed in BalanceMED as a percentage of drainage for each hydrological unit and calculated as:

$$
R(\%)=(A+S+3 L+2 I+S) / 90
$$

Where $A$ is the Altitude, $S$ is the Slope, $L$ is the Lithology, I the preferential Infiltration layers and $S$ the Soil. Punctuation categories are established for each variable between one (minimal influence in recharge) and ten (maximum influence). In our study, slope was corrected to zero for agricultural land uses in order to introduce the leveling effect of terraces. These parameters are averaged for HU grain.

\section{Model calibration, validation and limitations}

A detail description of BalanceMED can be found in Willaarts et al. 2012. For this study, the model was translated from a Microsoft Excel macro to an $\mathrm{R}$ script to gain flexibility for future implementations. Model calibration was done through standard hydrograph plot (Figure 3). Monthly volumetric runoff rates are recorded at the only one available gauging station in the basin for the time series 1971-2000. Mean-monthly values of observed runoff were contrasted against model runoff. The peak of runoff in April responds to the monthly precipitation pattern but is not 
observed in the gauging station likely because it is the month were irrigation starts and pools are filled with diversions from river.

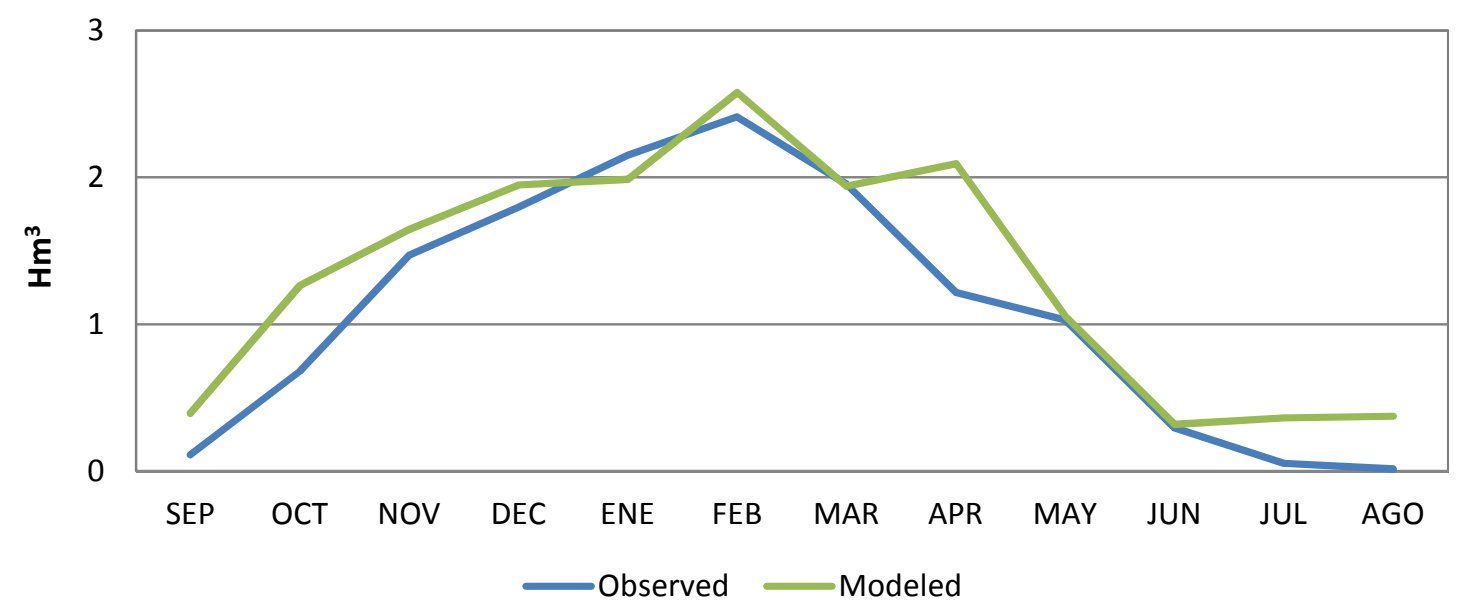

Figure 3 - Plot of observed vs modeled runoff volumetric rates

In order to validate results, the evaluation statistics recommended by Moriari et al. 2007 were used: (i) the Nash-Sutcliffe efficiency (NSE) which indicates how well the plot of observed versus simulated data fits the 1:1 line, (ii) the Percent bias (PBIAS) which measures underestimation tendency of the model and (iii) the RMSE-observations standard deviation ratio (RSR), which is a standardized version of the root mean square error. The model performance can be judged as satisfactory according to these criteria (NSE $>0.50$ and RSR $<0.70$, and if PBIAS $\leq 25 \%$ for streamflow) (Table 2). The model efficiency shows a good plot fit between observed and simulated data. The PBIAS indicate a slight overestimation of runoff.

Table 2 - Model evaluation of BalanceMED. Three metrics were calculated to validate modelresults: Nash-Sutcliffe efficiency (NSE) (range $=-\infty / 1$, optimum 1); Percent bias (PBIAS) (range $=-\infty /+\infty$, optimum 0 ); and RMSE-observations standard deviation ratio (RSR)(range $=0 /+\infty$, optimum 0).

\begin{tabular}{|c|c|}
\hline Statistics & Value \\
\hline NSE & 0.80 \\
\hline PBIAS & 12.00 \\
\hline RSR & 0.44 \\
\hline
\end{tabular}

\section{Post processing water grammar variables}

Main results from BalanceMED are the volumetric variables of recharge, runoff, soil infiltration, transpiration and evaporation on a monthly and HU resolution. Intensive variables ( $\mathrm{mm} \mathrm{or} \mathrm{m}^{3} / \mathrm{ha}$ ) used for spatial analysis of ecosystems-water funds relation are obtained by weighted means per area for each type of LULC considered. Extensive volumetric variables (total $\mathrm{Hm}^{3}$ ) were obtained by aggregation per $\mathrm{HU}$ area. 


\section{Societal metabolism}

\section{Human activity}

A thorough description of human activity accounting can be found in Kovacic and Ramos-Martin 2014. The Total Human Activity in a given society is calculated in hours as:

$$
\text { THA }_{\text {year }} i=365 * 24 * \text { Population }_{\text {year }} i
$$

This total is disaggregated in subsequent hierarchical levels according to case-study objectives. In our case, the categories considered are explained in Table 1 and the equation to valid is:

$$
T H A_{2005}=H A_{P O}+H A_{S L E}+H A_{U W}+H A_{P W}
$$

Where $P O$ is physiological overhead; SLE is social, leisure and education; UW is unpaid work; $P W$ is paid work. These variables were calculated for each municipality with data on employment, occupation, education and demographic structure from Spanish Census of Population and Households 2001 and the Time Use Survey 2002-03 for Almeria province. This latter establishes shares of hours devoted to the different activities in a day per age ranges. Since that information is only available every ten years in Spain, the obtained human activity shares were then extrapolated to the population evolution until 2005. Considering there was not mayor societal changes those years (pre economic crisis 2008 scenario), it is a reasonable assumption. The new census 2011 collected data from 2011 to 2013 and did not reach the same detailed level of municipality for required data inputs. For this reason it is not possible to update the human activity budget.

\section{Land uses}

Two geographical layers were used for the land budget analysis: the Map of Land Uses and Covers of Andalusia 2003 (MLUCV03) and the Inventory and characterization of irrigation in Andalusia 2008 (ICIA08). This latter collected data through surveys to Irrigation Communities from 2002 to 2008 and is the baseline used for the RBMP. It contains crops surface per irrigation community. Categories of irrigated agriculture in the MLUCV03 were coerced to match those of the ICIA08. For the rest of land uses and covers, we broke the hierarchical structure of the MLUCV03 in order to group them in types and levels relevant our analysis. MLUCV03 was intersected with the parks boundaries to obtained categories of land management. For each type of LULC and protection category (High protection in the National Park, Medium protection in the Natural Park, no protection in the rest of the watershed) a land use ratio was assigned as shown in Table 3.

Table 3 - Land and soil water use coefficients.

\begin{tabular}{|l|c|c|c|l|}
\hline & $\begin{array}{c}\text { High } \\
\text { protection }\end{array}$ & $\begin{array}{c}\text { Medium } \\
\text { protection }\end{array}$ & $\begin{array}{c}\text { Not } \\
\text { protected }\end{array}$ & \multicolumn{1}{|c|}{ Water uses } \\
\hline Irrigated agriculture & 1 & 1 & 1 & Irrigated agriculture \\
\hline Rainfed agriculture & 1 & 1 & 1 & Rainfed agriculture \\
\hline Abandoned & 0 & 0 & 0.2 & Grazing \\
\hline Quercus forest & 0 & 0.1 & 0.2 & Forestry \\
\hline Pine plantations & 0 & 0.1 & 0.2 & Forestry \\
\hline Riparian forest & 0 & 0 & 0 & \\
\hline Shurbs & 0 & 0.2 & 0.3 & Grazing $(2 / 3)$ and \\
\hline
\end{tabular}




\begin{tabular}{|l|c|c|c|l|}
\hline & & & & gathering (1/3) \\
\hline Pastures & 0 & 0.3 & 0.5 & Grazing \\
\hline Urban & 0 & 1 & 1 & Urban supply \\
\hline
\end{tabular}

Monetary flows and technical capital

Crops economic data and irrigation infrastructures were also double-sourced:

- Irrigated crops: Gross Added Value/ha, Working Days/ha, agriculture Inputs Costs/ha and Water Costs (cent $€ / \mathrm{m}^{3}$ ) were obtained from ICIA08. The type of trade (exports, local or self-consumption) and water supply and irrigation systems are also included in this database. Total extensive variables were obtained for each type of crop and trade.

- Rain-fed crops: production in Tons/ha per type of crops and prices received by farmers in $€ / 100 \mathrm{~kg}$ were obtained from the annual statistics on agriculture and fishing of Andalusia 2005. Total Gross Added Value per crop was estimated based on the surface of rain-fed agriculture land uses.

There is no available data of added value for other economic activities than agriculture at municipal level. The total Gross Rent in the basin is calculated aggregating for each municipality rent per capita.

\section{Water use}

Water withdrawals and use were obtained from three sources:

- The Andalusia Mediterranean River Basins Management Plan 2009-2015, which includes extraction from different sources, water allocation to different uses and average irrigation efficiencies.

- The Inventory and characterization of irrigation in Andalusia 2008-ICIA08 contains data on gross water use for each irrigation community from different sources. Net water use was estimated by multiplying for the average efficiency in their area.

- The report from Martinez 2011 is the only data source with actual urban gross and net water use measured data for all municipalities in the Almeria province as well as water sources.

These variables are provided for one year. For seasonal analysis, monthly irrigation was estimated based on schedules from the technical assistance to farmers system of the Andalusian government and personal communication from farmers in the area. Multi-crops areas were averaged. Urban water was broken into equal monthly shares for residents and commercial uses and nonresidential use was added to summer months. Water withdrawals were spatialized by splitting the river length in segments according to water withdrawal points by each municipality and irrigation community. Soil water use is calculated applying the same coefficients of land covers use and relating them to activities presented in Table 3. Gross water use is the total evapotranspiration and net water use is transpiration in those covers. The separation of transpiration from irrigation 
and from rain water was obtained by the difference between running the model with and without irrigation.

\section{Ecosystem health}

The assessment of the ecological status of water bodies is the baseline of the RBMP. Aquifers are evaluated on their quantitative (exploitation index) and qualitative (pollution) status. Rivers are evaluated on their biological (biodiversity), hydro-morphological and physic-chemical status. The information provided in the plan is rather dated (only one sampling campaign) and the final evaluation based on expert evaluation. We provide additional analysis of available secondary data to complement and discuss this assessment: erosion rates, water table levels and surface and groundwater quality.

The cartography of average erosion rates for the period 1992-2006 is available at the natural hazards section of the Andalusian Network of Environmental Information [Online] URL: http://www.juntadeandalucia.es/medioambiente/site/rediam/portada/. The calculation method used by the Andalusian Environment Agency is the Universal Soil Loss Equation (USLE) and the scale set by this institution by normalizing the range of average soil loses values in the region from low ( $<12$ ton/ha yr) to high ( $>50$ ton/ha yr). Water table levels change was also averaged for the available series from 1992-2006 from the network of piezometers of the Spanish Institute of Geology and Mining Water Database [Online] URL: http://info.igme.es/BDAguas/. There are more control piezometers but only 32 have data and 22 data for the selected period. Most series stop in 2004 and there is no data afterwards in this database. The Spanish Ministry of Environment has been monitoring only 9 of them from 2006 on. The decrease in water table monitoring points is therefore considerable. Groundwater and surface water quality variables have been download from the Andalusian River Basins Network for physic-chemical and biological control of water quality, which contains all the sampling campaigns from 2002 to 2013 [Online] URL: http://laboratoriorediam.cica.es/Visor DMA/?urlFile=http://laboratoriorediam.cica.es/Visor DMA Lservice $\mathrm{xml} /$ capas dma.xml]. Available series for this period for each control point were averaged.

Regarding ecosystems water requirements, land ecosystems transpiration is a result from BalanceMED, environmental flows for the river are proposed in the RBMP on a monthly volumetric rate and aquifer discharges to springs and other connected aquifers were estimated in the Hydrogeological Atlas of Andalusia 1980-1990 [Online] URL: http://aguas.igme.es/igme/publica/libros1 HR/libro110/Pdf/lib110/in 32.pdf.

\section{LITERATURE CITED}

Allen, T. F. H., and T. W. Hoekstra. 1992. Towards a unified ecology. Columbia University Press. New York, New York, USA.

Andreo, B., J. Vías, J. A. López-Jeta, F. Carrasco, J. J. Durán, and P. Jiménez. 2004. Propuesta metodológica para la estimación de la recarga de acuíferos carbonáticos. Boletín Geológico Minero 115:177-186. 
Camara, R., and B. Martinez. 2002. HidroBio.V3.0. Plantilla para el cálculo del balance hídrico y el diagrama bioclimático: su aplicación a estudios de hidrología y geobotánica. Equipo de Trabajo Estudios Tropicales y Cooperación al Desarrollo del Grupo de Investigación Cuaternario y Geomorfología (PAI RNM-273). Departamento de Geografía Física y Análisis Geográfico Regional, Universidad de Sevilla.

Kovacic, Z., and Ramos-Martin, J. 2014. Accounting for human activity and socio-economic characteristics. In Giampietro et al (Eds.) Resource Accounting for Sustainability Assessment: The Nexus between Energy, Food, Water and Land Use. Routledge Explorations in Sustainability and Governance. Routledge, New York, New York, USA.

Madrid, C. , J.J. Cadillo-Benalcazar, F. Diaz-Maurin, Z. Kovacic, T. Serrano-Tovar, T. Gomiero, M. Giampietro, R. J. Aspinall, J. Ramos-Martin and S. G.F. Bukkens. 2014. Punjab state, India. In Giampietro et al (Eds.) Resource Accounting for Sustainability Assessment: The Nexus between Energy, Food, Water and Land Use. Routledge Explorations in Sustainability and Governance. Routledge, New York, New York, USA .

Martinez, J. 2011. Energy Footprint of the urban water supply in Almeria province. [online] URL: http://repositorio.ual.es:8080/ispui/bitstream/10835/1152/1/Estudio\%20de\%20la\%2OHuella\%20E nergetica\%20del\%20Abastecimiento\%20Urbano\%20de\%20Agua\%20de\%20la\%20Provincia\%20de \%20Almeria Martinez\%20Rodriguez,\%20Francisco\%20Javier.pdf.

Moriasi, D. N., J. G. Arnold, M. W. Van Liew, R. L. Bingner, R. D. Harmel, and T. L. Veith. 2009. Model evaluation guidelines for systematic quantification of accuracy in watersheds simulations. American Society of Agricultural and Biological Engineers 50(3): 885-900.

Ravera F., Gamboa G., Scheidel A., Dell'Angelo J., Serrano T., Mingorría S., Cabello V., Ariza P., and Arizpe N. 2014. Pathways of rural change: An integrated Assessment of the metabolic patterns of emerging ruralities. Environment Development and Sustainability 16: 1-10.

Scheidel, A. 2013. From MUSIASEM theory to practice: report and reflections from field research in Kampot province, Cambodia Recer. ICTA working paper Dipòs. Recer. Catalunya. [online] URL: http://www.recercat.net/handle/2072/209216.

Serrano-Tovar, T. and M. Giampietro.2014. Multi-scale integrated analysis of rural Laos: Studying metabolic patterns of land uses across different levels and scales. Land Use Policy 36:155-170.

Willaarts, B.A., M. Volk, and P.A. Aguilera. 2012. Assessing the ecosystem services supplied by freshwater flows in Mediterranean agroecosystems. Agricultural Water Management 105:21-31. 